OPEN ACCESS

Edited by:

Cinzia Corinaldesi,

Marche Polytechnic University, Italy

Reviewed by:

Cristina Linares,

University of Barcelona, Spain

Daniela Pica,

Marche Polytechnic University, Italy

*Correspondence:

Laurence Helene De Clippele laurence.de.clippele@gmail.com

Specialty section:

This article was submitted to Deep-Sea Environments and Ecology, a section of the journal Frontiers in Marine Science

Received: 14 November 2018 Accepted: 21 March 2019 Published: 09 April 2019

Citation:

De Clippele LH, Huvenne VAl, Molodtsova TN and Roberts JM (2019) The Diversity and Ecological Role of Non-scleractinian Corals (Antipatharia and Alcyonacea) on Scleractinian Cold-Water Coral Mounds. Front. Mar. Sci. 6:184 doi: 10.3389/fmars.2019.00184

\section{The Diversity and Ecological Role of Non-scleractinian Corals (Antipatharia and Alcyonacea) on Scleractinian Cold-Water Coral Mounds}

\author{
Laurence Helene De Clippele ${ }^{1 *}$, Veerle A. I. Huvenne ${ }^{2}$, Tina N. Molodtsova ${ }^{3}$ and \\ J. Murray Roberts ${ }^{1}$
}

'School of Geosciences, Grant Institute, The University of Edinburgh, Edinburgh, United Kingdom, ${ }^{2}$ Marine Geoscience, National Oceanography Centre, University of Southampton, Southampton, United Kingdom, ${ }^{3}$ P.P. Shirshov Institute of Oceanology, Russian Academy of Sciences, Moscow, Russia

Cold-water coral carbonate mounds, created by framework-building scleractinian corals, are also important habitats for non-scleractinian corals, whose ecology and role are understudied in deep-sea environments. This paper describes the diversity, ecology and role of non-scleractinian corals on scleractinian cold-water coral carbonate mounds in the Logachev Mound Province, Rockall Bank, NE Atlantic. In total ten non-scleractinian species were identified, which were mapped out along eight ROV video transects. Eight species were identified as black corals (three belonging to the family Schizopathidae, one each to the Leiopathidae, Cladopathidae, and Antipathidae and two to an unknown family) and two as gorgonians (Isididae and Plexauridae). The most abundant species were Leiopathes sp. and Parantipathes sp. 2. Areas with a high diversity of non-scleractinian corals are interpreted to offer sufficient food, weak inter-species competition and the presence of heterogeneous and hard settlement substrates. A difference in the density and occurrence of small vs. large colonies of Leiopathes sp. was also observed, which is likely related to a difference in the stability of the substrate they choose for settlement. Non-scleractinian corals, especially black corals, are an important habitat for crabs, crinoids, and shrimps in the Logachev Mound Province. The carrier crab Paromola sp. was observed carrying the plexaurid Paramuricea sp. and a black coral species belonging to the genus Parantipathes, a behavior believed to provide the crab with camouflage or potentially a defense mechanism against predators. More information on the ecophysiology of nonscleractinian corals and fine-scale local organic matter supply are needed to understand what drives differences in their spatial distribution and community structure.

Keywords: cold-water coral mounds, fine-scale spatial patterns, biodiversity, associated megafauna, Antipatharia, Alcyonacea, Logachev Mound Province 


\section{INTRODUCTION}

Lophelia pertusa and Madrepora oculata, the dominant reefforming scleractinian corals in the deep sea, have been widely studied over the last 20 years. However, due to the high biodiversity and the numerous symbiotic associates they have, non-scleractinian corals should not be overlooked (e.g., BuhlMortensen and Mortensen, 2005; Etnoyer and Morgan, 2005; Tazioli et al., 2007; Cerrano et al., 2010; Wagner et al., 2012; Corbera Pascual, 2015; Cúrdia et al., 2015; De Clippele et al., 2015). This is because non-scleractinian corals are known to be an important habitat for a diverse range of organisms providing, e.g., a feeding platform, a place to shelter or a substrate for fish to lay their eggs on (Buhl-Mortensen and Mortensen, 2004; Le Guilloux et al., 2010; Wagner et al., 2012; De Clippele et al., 2015). In this study, we will discuss the non-scleractinian corals belonging to the Antipatharia and Alcyonacea.

Antipatharia also referred to as black corals (Cnidaria: Anthozoa: Hexacorallia) encompass seven families (Wagner et al., 2012) with $75 \%$ (c. 180 species) found below $50 \mathrm{~m}$ depth (Cairns, 2007). The black corals' lifespan is greater than most other deep-sea coral species (Andrews et al., 2001, 2009; Roark et al., 2009). A Leiopathes annosa (Wagner and Opresko, 2015), colony from Hawaiian (United States) waters was estimated to be 4,265 years old with radial growth rates between 0.005 and $0.022 \mathrm{~mm} \mathrm{yr}^{-1}$ (Roark et al., 2009; Sherwood and Edinger, 2009).

Gorgonians (Cnidaria: Anthozoa: Octocorallia) belong to the Order Alcyonacea can be found at virtually any depth, with records found as deep as $5850 \mathrm{~m}$ (Madsen, 1956). They can be found in most ocean basins and can live over 100 years (Hill et al., 2011; Watling et al., 2011; Lacharite and Metaxas, 2013). Octocorals grow faster and have lower lifespans than black coral species, with radial growth rates between 0.05 and $0.44 \mathrm{~mm} \mathrm{yr}^{-1}$ (Watling et al., 2011).

Given their slow growth rates and great longevity, coldwater black corals and octocorals are particularly vulnerable to anthropogenic damage. Disturbance and removal through bottom fishing (Althaus et al., 2009) and exploitation for commercial therapeutic and jewelry/art use (Grigg, 2001) are significant threats. Deep-water black and octocorals are part of "Vulnerable Marine Ecosystems" (VME) as defined by United Nations General Assembly Resolutions 61/105 and 64/72 (Fuller et al., 2008).

This study focussed on the non-scleractinian corals that grow on the cold-water coral carbonate mounds in the Logachev Mound Province, Rockall Bank. While black corals and deepsea gorgonians corals have been reported in this area in previous studies (Duineveld et al., 2007; Roberts et al., 2008; Henry et al., 2014) their community characteristics, ecology and functional roles have not been studied.

Cold-water coral carbonate mounds are topographic structures that owe their existence, partially or entirely, to the growth of scleractinian framework building corals, such as Lophelia pertusa and Madrepora oculata (Freiwald, 2002; Roberts et al., 2006). These mound structures have developed over glacial-interglacial time periods and vary widely in size and shape (Kenyon et al., 2003; Van Weering et al., 2003;
Mienis et al., 2007; Wheeler et al., 2007). Both box core samples and video footage have revealed that cold-water coral carbonate mounds are associated with a high diversity of organisms (Raes et al., 2003; Raes and Vanreusel, 2005, 2006; Wheeler et al., 2005; Henry and Roberts, 2007). Corals are suspension feeders and have been shown to be more abundant on- vs. off-mound (Henry and Roberts, 2007). Soetaert et al. (2016) showed that at Rockall Bank, there is a significant interaction between tidal currents and cold-water coral formed mounds which induce downwelling events of surface water that brings the organic matter to $600 \mathrm{~m}$ deep. Therefore, the greater resuspension of particulate organic matter and the high currents keeping sedimentation rates low could explain why both filter and suspension feeders are more abundant on the mounds (Henry and Roberts, 2007). These characteristics make cold-water coral mounds important features to study regarding non-scleractinian coral presence and diversity. The dominant non-scleractinian fauna varies across European cold-water coral reef ecosystems with, for example, black corals dominating the Belgica Mound Province (Henry and Roberts, 2007), while gorgonians corals dominate reefs in Norwegian fjords (Mortensen et al., 1995). This difference could be a consequence of variability in hydrography, topography, and the biological traits of the species themselves, which is interrelated to the mound or reefs' size and complexity of the habitat (Ricklefs and Lovette, 1999).

Therefore, this study aims to: (1) document the diversity of these non-scleractinian corals on cold-water coral carbonate mounds, (2) determine what environmental conditions influence differences in their density, and (3) investigate their potential ecological role. The goal of this study is to provide more information on these non-scleractinian corals to ensure that better-informed decisions can be made to protect these longlived organisms.

\section{MATERIALS AND METHODS}

\section{Study Area}

The Logachev Mound Province is located on the south-eastern slope of Rockall Bank in the northeast Atlantic (Kenyon et al., 2003; Figure 1). Within Rockall Trough, the upper layers down to 1,200-1,500 m are occupied by Eastern North Atlantic Water (ENAW) (Holliday et al., 2000). The cold-water coral carbonate mounds are between 5 and $360 \mathrm{~m}$ tall, up to a few kilometers long and located between 600 and $1000 \mathrm{~m}$ depth, which is within the boundaries of the ENAW (Kenyon et al., 2003; Mienis et al., 2007, 2009; de Haas et al., 2009). The ENAW circulates through an anticyclonic gyre in Rockall Trough with a net northward flow direction, while around the mounds there is a local residual current flow toward the south-west that ranges between 5 and $15 \mathrm{~cm} \mathrm{~s}^{-1}$ (Huthnance, 1986; Holliday et al., 2000; Mienis et al., 2007; White et al., 2007; Soetaert et al., 2016). There is also a stronger bottom-magnified diurnal tidal flow of $15-28 \mathrm{~cm} \mathrm{~s}^{-1}$. It is these strong northwest-southeast directed currents that affect the growth direction of the mounds, which is perpendicular to the regional contours (Mienis et al., 2007; White et al., 2007). 


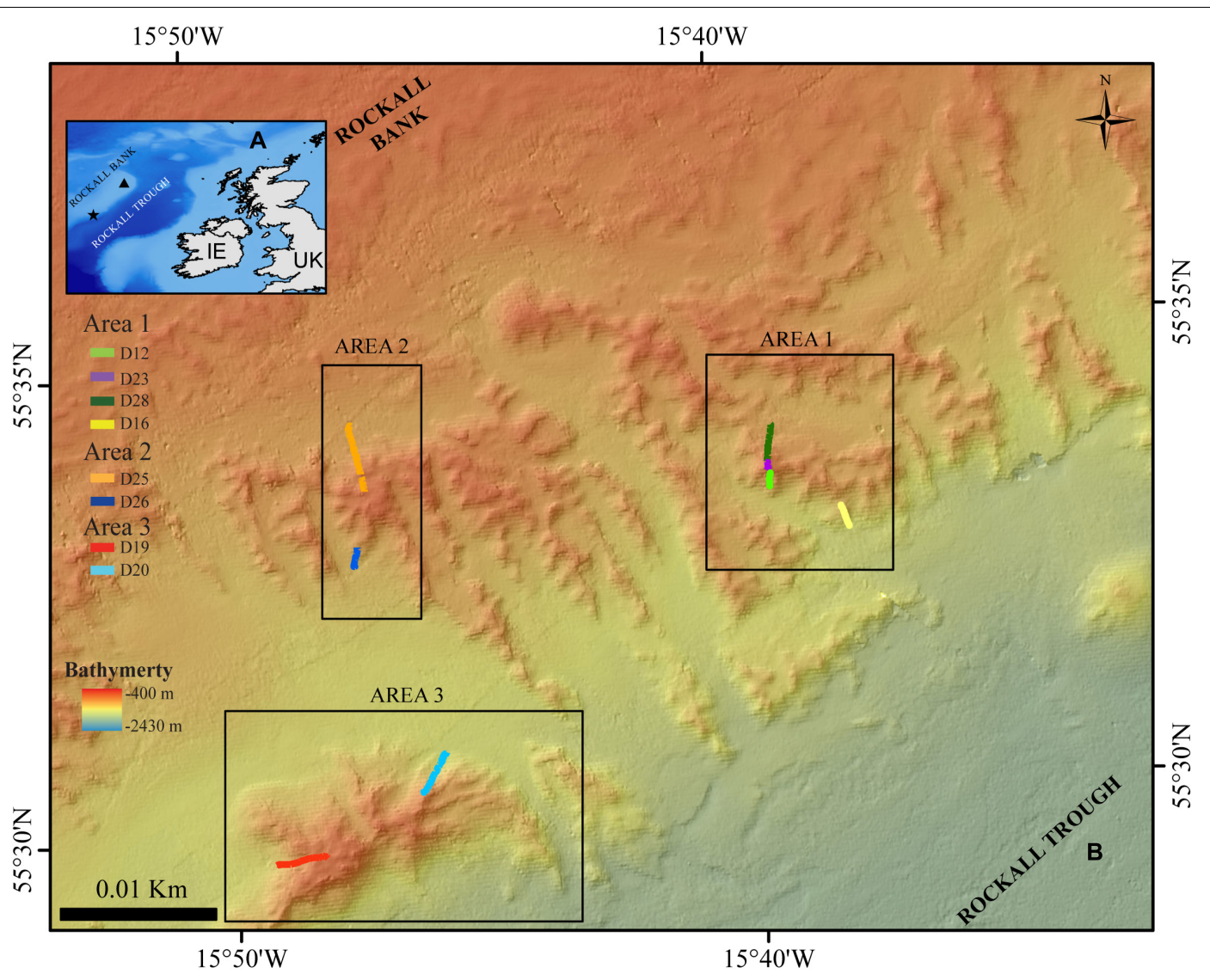

FIGURE 1 | (A) Location map of the Logachev Mound Province (star), and Rockall Island (triangle) on Rockall Bank. IE: Ireland (B) Location of the three study areas and ROV dives in the Logachev Mound Province on the south-east side of Rockall Bank.

The Logachev Mound Province consist of a cluster of mounds that are built of accumulated fine sediments baffled by coral reef framework, dead coral fragments and live coral on the summit. The mound bases are covered by bio- and siliciclastic sands with various amounts of pebbles, cobbles and boulders (de Haas et al., 2009). The flanks of the mounds are covered with patches of coral rubble, dead coral branches and living corals, while the summits of the mounds are characterized by dense $L$. pertusa patches at 500-600 m depth (Kenyon et al., 2003; Van Weering et al., 2003; de Haas et al., 2009).

Food is supplied to the suspension-feeding corals through different mechanisms. First, the presence of the coral framework will slow down the currents allowing the corals to gather food, but also trap sediments, which can then accumulate between the coral branches ensuring further growth of the mounds as a whole (Roberts et al., 2006; Dorschel et al., 2007; de Haas et al., 2009; Mienis et al., 2009; Roberts et al., 2009). Secondly, the interaction of the diurnal tidal currents with the slope of Rockall Bank and the topographies of the cold-water coral mounds themselves, induces downwelling of the productive Rockall Bank surface waters due to the formation of internal waves (Kenyon et al., 2003; Davies et al., 2009; Wagner et al., 2011; Findlay et al., 2013; Cyr et al., 2016; Soetaert et al., 2016). Thirdly, the interaction of internal waves and tidal currents with seabed sediments also causes nepheloid layers, which contain increased amounts of suspended seabed sediment that can supply the corals with food at deeper depths (Kenyon et al., 2003; Mienis et al., 2007). Intermediate Nepheloid Layers (INL) have been identified as turbidity clouds between 450 and $900 \mathrm{~m}$ depth and varied in depth and shape coincidingly with the diurnal cycle. The largest turbidity cloud can be found between 200 and $500 \mathrm{~m}$ depth, just above the carbonate mounds. A second smaller turbidity cloud can be found $25 \mathrm{~km}$ from Rockall Bank between 500 and $700 \mathrm{~m}$ depth (White et al., 2003; Mienis et al., 2006, 2007).

\section{High-Definition Video Data Video Data Acquisition}

In the Logachev Mound Province, genera belonging to the Order Antipatharia Milne-Edwards and Haime (1857) (black corals), as well as the Order Alcyonacea Lamouroux 1816, were present and studied here using high definition (HD) video recordings from remotely operated vehicles (ROVs). Highdefinition video data were collected in the Logachev Mound Province in 2012 (RRS James Cook Cruise 073, May 18-June 15, 2012) as part of the Changing Oceans 2012 expedition, using the ROV Holland-1. The data were recorded with a combination of cameras mounted on the ROV: an HD Insite 
mini-Zeus video camera with a direct HDSDI fiber output, a Kongsberg 14-208 digital stills camera, a Kongsberg 14-366 pan and tilt camera and an Insite Pegasus-plus fixed zoom camera. Four lights were used: two 400-W deep-sea power and light SeaArc2 HMI lights and two 25,000 lumen Cathx ocean APHOS LED lights. Two lasers spaced $10 \mathrm{~cm}$ were also mounted on the HD camera. The position and depth of the ROV were determined by USBL (Sonardyne) underwater positioning system and recorded using the OFOP (Ocean Floor Observation Protocol) software.

During the Changing Oceans Expedition, a total of eight video transects were recorded in the Logachev Mound Province with a total length of $\sim 3.4 \mathrm{~km}$ and an average width of $2.74 \mathrm{~m} \pm 0.5 \mathrm{~m}$. These eight video transects only covered small parts, on alternating sides of three large clustered cold-water coral carbonate mounds within the Logachev Mound Province (Figure 1 and Table 1). Since the transects only cover a section and not the whole of the clustered mound, they are referred to as area 1, 2, and 3. Based on Soetaert et al. (2016), it is known that the supply of organic matter varies with depth along the flank of Rockall Bank. It is therefore relevant to note that these three areas are located at different distances on the slope of Rockall Bank from the shallowest point, i.e., Rockall Island (Figure 1). Area 1, at 560-700 m depth, is located $\sim 26.1 \mathrm{~km}$ from Rockall Island, area 2 at $530-700 \mathrm{~m}$ depth is located $\sim 25.7 \mathrm{~km}$ and area 3 at $530-850 \mathrm{~m}$ depth is located $\sim 26.8 \mathrm{~km}$ from Rockall Island.

\section{Substrate Classification}

Substrate types were identified from the HD videos according to the classes listed in Table 2 (see Table 2 and Figure 2) and noted in Excel. The dominant substrate class was noted every meter from the HD videos for which the percentage cover for each substrate class were calculated per flank and area.

\section{Coral Identification and Associated Fauna}

The presences of non-scleractinian coral species were noted for every meter in Excel, alongside the notes on the dominant substrate class. Preliminary evaluation of the HD videos indicated a large number of occurrences of different size classes of the black coral species Leiopathes sp., which was therefore classified as small $(<30 \mathrm{~cm})$, medium $(30-100 \mathrm{~cm})$, or large $(>100 \mathrm{~cm})$.
The associated mobile megafauna was identified from the HD video and their location on the coral colonies specified as central branch versus the outer branch, and on the base, middle or top part of the colonies.

\section{Analyses}

The HD video dive transects that were used for analyses varied from 40 to $1040 \mathrm{~m}$ in length (Table 1). The video transects were systematically subsampled into a total of 84 groups located at a distance of $40 \mathrm{~m}$ to reduce the influence of spatial autocorrelation for statistical analyses (Table 1). The length of $40 \mathrm{~m}$ was chosen as this length gave the best representation of the substrate and species variability in relation to a changing bathymetry and rugosity. The ArcGIS "Join" function was used to calculate the total number of counts for each non-scleractinian coral species per sub-sample.

\section{Diversity, Evenness, and Density}

The species diversity, density, and evenness of all nonscleractinian corals were calculated in the PRIMER software (Clarke and Warwick, 2001). The data matrix composed of the sub-sample number ( $y$-axis) and the counts of the nonscleractinian species found per $40 \mathrm{~m}$ sub-sample (x-axis). Two types of factors were added. A first identifying the location of the sub-sample (area 1, 2 or 3), and a second factor identifying the flank the sub-sample was located on (NE, S, NW, SW). Shannon diversity index $\left(\mathrm{H}^{\prime}\right)$ and Pielou value were used to calculate the diversity and evenness of the non-scleractinian corals in the study area. The Pielou's evenness value can range from 0 to 1 , and gives an indication of dominant species being present in a sample $(\sim 0)$ or if there is an equal abundance of all species $(\sim 1)$. Density was calculated for all the non-scleractinian corals together and for the species separately, by dividing their total counts by the total square meter which covered per $40 \mathrm{~m}$ sub-sample. When the video transects were recorded the ROV varied in height, affecting the average width, and thus the total area of the transect. The average width of the video transects can be found in Table 1. When a density calculation was made including two or more different video transects, their average width was used to calculate the total area covered. The number of different species counted per area and flank were also calculated in Excel.

TABLE 1 | Remotely operated vehicle dive information.

\begin{tabular}{|c|c|c|c|c|c|c|c|c|}
\hline $\begin{array}{l}\text { Dive } \\
\text { (area) }\end{array}$ & $\begin{array}{l}\text { Start Lon } \\
\text { (decimal } \\
\text { degrees) }\end{array}$ & $\begin{array}{l}\text { Start Lat } \\
\text { (decimal } \\
\text { degrees) }\end{array}$ & $\begin{array}{l}\text { End Lon } \\
\text { (decimal } \\
\text { degrees) }\end{array}$ & $\begin{array}{l}\text { End Lat } \\
\text { (decimal } \\
\text { degrees) }\end{array}$ & $\begin{array}{l}\text { Aspect/ } \\
\text { flank }\end{array}$ & $\begin{array}{l}\text { Depth range } \\
\text { (min-max) (m) }\end{array}$ & $\begin{array}{l}\text { Length/ } \\
\text { Width (m) }\end{array}$ & $\begin{array}{l}\text { No. Sub- } \\
\text { samples }\end{array}$ \\
\hline $12(1)$ & -15.65523 & 55.55799 & -15.65557 & 55.55567 & NE & $(640-722)]$ & 200/2.36 & 5 \\
\hline $16(1)$ & -15.63350 & 55.55119 & -15.63142 & 55.547439 & S & $(758-874)$ & $240 / 2.82$ & 6 \\
\hline $23(1)$ & -15.65630 & 55.55847 & -15.65571 & 55.55965 & $\mathrm{NE}$ & $(563-584)$ & $40 / 2.55$ & 1 \\
\hline $28(1)$ & -15.65585 & 55.56014 & -15.65389 & 55.56674 & $S$ & $(575-701)$ & $240 / 2.91$ & 6 \\
\hline $25(2)$ & -15.78718 & 55.57206 & -15.78421 & 55.56013 & NW & $(547-705)$ & 1040/3.37 & 26 \\
\hline $26(2)$ & -15.78795 & 55.55020 & -15.78918 & 55.54672 & SW & (702-768) & $360 / 2.79$ & 9 \\
\hline 19 (3) & -15.82089 & 55.49419 & -15.80442 & 55.49478 & NE & (559-801] & 880/2.62 & 22 \\
\hline $20(3)$ & -15.76447 & 55.51220 & -15.77232 & 55.50529 & NW & (610-873] & $360 / 2.97$ & 9 \\
\hline
\end{tabular}

Average aspect represents the side of the area/clustered mound at which the video transects were collected. 
TABLE 2 | Substrate classes identified in HD video data.

\begin{tabular}{ll}
\hline Substrate type & Abbreviation \\
\hline L. pertusa thicket & LpT \\
$\begin{array}{l}\text { Dead exposed L. pertusa framework with scarce live } \\
\text { L. pertusa colonies }\end{array}$ & DEC \\
Coral rubble & $\mathrm{CR}$ \\
Lithified hardground & $\mathrm{LiH}$ \\
Fine sediment with pebbles, cobbles, and boulders & $\mathrm{FS} / \mathrm{P} / \mathrm{C} / \mathrm{B}$ \\
$(<100$ cm diameter) & \\
Mixed sediment with large boulders $(>100 \mathrm{~cm})$ & $\mathrm{MS} / \mathrm{LB}$ \\
Fine sediment & $\mathrm{FS}$ \\
\hline
\end{tabular}

\section{Environmental Drivers of Spatial Variation in Density}

The change in the density of the non-scleractinian species was studied in relation to the substrates and to environmental variables that were extracted from bathymetry data. Substratum information was obtained from video data (see section "Substrate Classification"). Terrain characteristics were extracted from a bathymetry dataset that was provided by the Irish National Seabed Survey programme (INSS) at a $20 \mathrm{~m} \times 20 \mathrm{~m}$ resolution ${ }^{1}$. Several topographic variables were derived from the bathymetric grid using the ArcGIS 10.1, ESRI Software and the Benthic Terrain Modeler (Wright et al., 2012): slope, aspect (eastness and northness), rugosity (calculated at two spatial scales, using a square kernel window of respectively $3 \times 3$ and $9 \times 9$ pixels) and bathymetric positioning index (BPI; calculated at two spatial scales using an annulus kernel window with inner and outer radius of respectively $3 \times 6$ and $6 \times 9$ cells). More information on these variables can be found in De Clippele et al. (2017) and,

${ }^{1}$ www.gsiseabed.ie

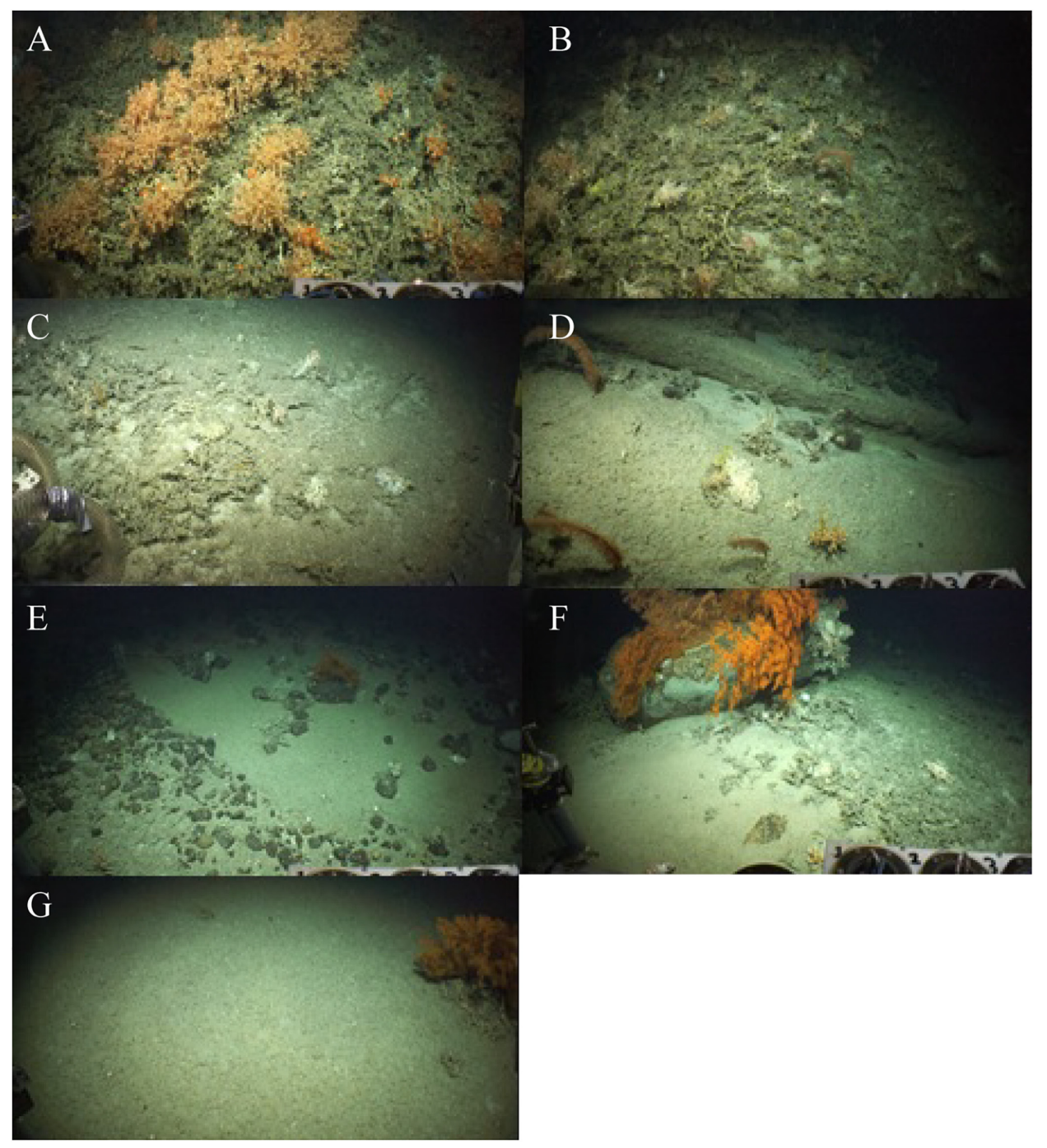

FIGURE 2 | Example photographs of substrate types identified in the Logachev Mound Province: (A) LpT, (B) DEC, (C) CR, (D) LiH, (E) FS/P/C/B, (F) MS/LB, (G) FS. 
for example, in Wilson et al. (2007), Guinan et al. (2009), and Henry et al. (2010).

Because the response variables did not follow a normal Gaussian distribution, the more flexible Generalized Linear Modeling (GLM) approach was used. The probability distributions of the coral density data analyzed here belong to the exponential quasi-Poisson family (McCullagh and Nelder, 1989; Dobson and Barnett, 2008). The statistical software package $\mathrm{R}$ was used to perform the GLM (R Development Core Team, 2010).

Linear regression cannot include missing values. Hence sub-samples that had no abundances of the analyzed species present were excluded (McCullagh and Nelder, 1989; Dobson and Barnett, 2008). Backward stepwise regression decided what environmental variables (\% occurrence of the seven substrate types and the variables derived from the bathymetry) contributed the most to the performance of the model. The best model was chosen based on the Akaike Information Criterion (AIC), which estimates if there is any uncertainty over the model (Cnaan et al., 1997; Symonds and Moussalli, 2011). Once the variables were selected, a GLM was performed. By taking the exponent of the coefficient values, the percentage change in the abundance of the coral per unit change of each explanatory variable was calculated. Species that had less than 50 individuals present were excluded from the statistical analyses due to the small sample size.

\section{RESULTS}

\section{Substrate Types}

Coral rubble (33.4\%), dead exposed L. pertusa framework (25.7\%), and fine sediment with pebbles, cobbles, and boulders (23.2\%), were the most abundant substrate types recorded in the entire studied area (area 1, 2, and 3). L. pertusa thickets covered $10.8 \%$, lithified hardground covered $4.2 \%$, fine sediment covered $2.3 \%$ while mixed substrate with large boulders covered just $0.4 \%$.

Dead exposed L. pertusa framework and coral rubble were present in high percentages in all the areas (Table 3). L. pertusa thickets were found predominantly in area 1 on the NE flank of the mound. A total of $\sim 39 \%$ of the terrain surveyed in area 2

TABLE 3 | Percentage contribution of the different substrates calculated from the HD video dive transects per area and per flank.

\begin{tabular}{lccccccc}
\hline Area & LpT & DEC & CR & LiH & FS/P/C/B & MS/LB & FS \\
\hline $\mathbf{1}$ (total) & $\mathbf{3 1 . 9 2}$ & $\mathbf{3 8 . 7 2}$ & $\mathbf{2 0 . 1 6}$ & $\mathbf{1 . 5 9}$ & $\mathbf{1 . 6 6}$ & $\mathbf{0 . 2 4}$ & $\mathbf{5 . 7 1}$ \\
1 NE & 24.93 & 19.84 & 1.40 & 0 & 0 & 0 & 0 \\
1 S & 6.99 & 18.88 & 18.76 & 1.59 & 1.66 & 0.24 & 5.71 \\
$\mathbf{2}$ (total) & $\mathbf{0 . 1 6}$ & $\mathbf{1 3 . 4 9}$ & $\mathbf{4 1 . 7 9}$ & $\mathbf{7 . 6 4}$ & $\mathbf{2 7 . 9 1}$ & $\mathbf{3 . 1 4}$ & $\mathbf{5 . 8 8}$ \\
2 NW & 0.16 & 7.58 & 11.41 & 4.15 & 20.52 & 2.43 & 1.31 \\
2 SW & 0 & 5.92 & 30.37 & 3.49 & 7.39 & 0.71 & 4.56 \\
3 (total) & $\mathbf{1 . 7 2}$ & $\mathbf{2 0 . 8 4}$ & $\mathbf{3 8 . 8 2}$ & $\mathbf{5 . 1 1}$ & $\mathbf{3 3 . 2 2}$ & $\mathbf{0 . 1 2}$ & $\mathbf{0 . 1 7}$ \\
3 NE & 0.01 & 3.13 & 3.30 & 0 & 0 & 0.01 & 0.06 \\
3 NW & 1.71 & 17.70 & 35.52 & 5.11 & 33.22 & 0.11 & 0.12 \\
\hline
\end{tabular}

The dives included per flank and area can be found in Table 1.

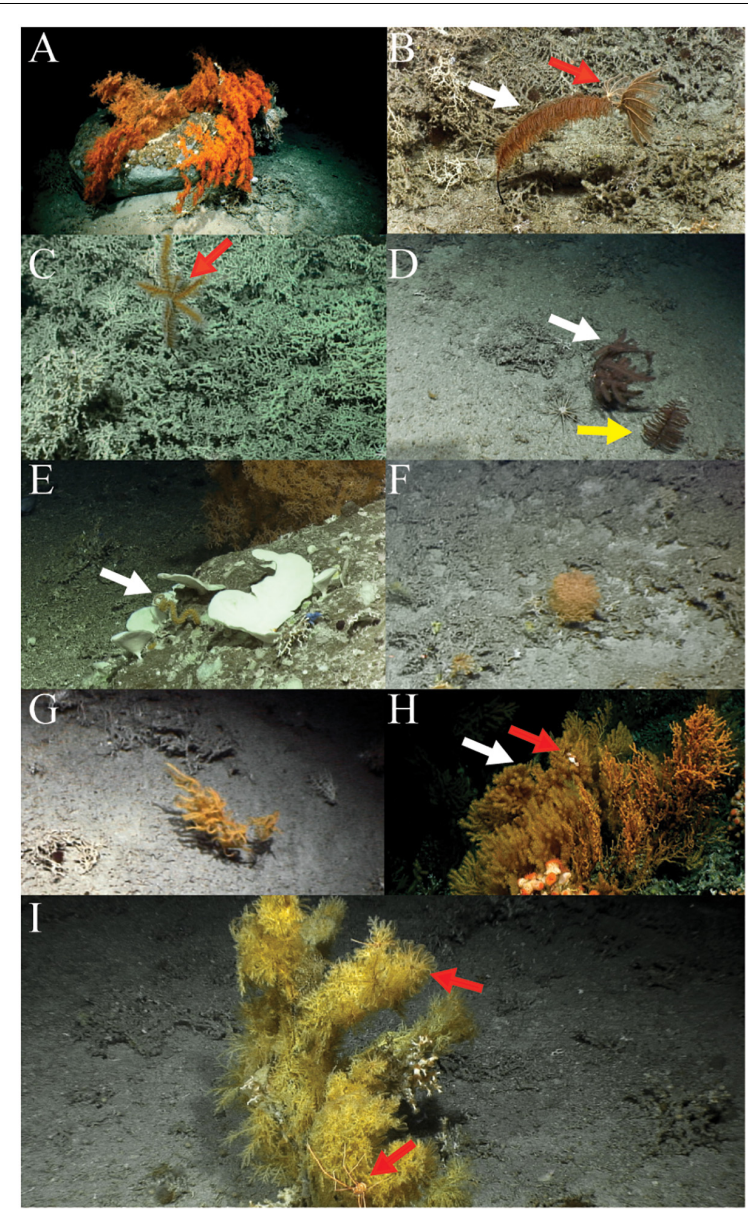

FIGURE 3 | (A) Leiopathes sp. (B) The white arrow points to Parantipathes sp. 1 and the red arrow points to two crinoids attached to the top of the coral. (C) Parantipathes sp. 2 with the red arrow indicating a shark egg case attached to it. (D) The white arrow points to Trissopathes sp. 1 and the yellow arrow to Bathypathes sp. (E) Stichopathes cf. gravieri indicated by the white arrow (F) Acanella sp. (G) Antipatharia sp. 2. (H) The white arrow points to Paramuricea sp. and the red arrow to a Gorgonocephalus sp. (I) Antipatharia $\mathrm{sp}$. 1 with the top red arrow pointing to attached crinoids and the bottom red arrow pointing to a Gastroptychus sp.

and 3 were covered with the hard substrates (pebbles, cobbles, boulders, large boulders, and lithified hardgrounds), mostly on the NW flank of their mounds. Area 1 had only $4 \%$ of these hard substrates present.

\section{Non-scleractinian Species}

Ten non-scleractinian coral species with a total 1,707 specimens were counted across the three Logachev mound areas. Black corals were the most abundant non-scleractinian corals, overall, with 1,695 individual black corals recorded. In total eight different black coral species were identified: three species belonging to the family Schizopathidae (Bathypathes sp., Parantipathes sp. 1, Parantipathes sp. 2), one species belonging to the families Leiopathidae (Leiopathes sp.), Cladopathidae (Trissopathes sp.), and Antipathidae (Stichopathes cf. gravieri) and 
two unidentified species which we refer to as Antipatharia sp. 1, Antipatharia sp. 2. Only two species belonging to the Order Alcyonacea were identified: one gorgonian coral belonging to the Isididae family (Acanella sp.) and one gorgonian belonging to the Plexauridae family (Paramuricea sp.). The different species are shown in Figure 3.

The black coral Leiopathes sp. was the most abundant antipatharian with a total of 1,583 individuals. The second most abundant coral was also a black coral species, Parantipathes sp. 1 , with 60 individuals. The other non-scleractinian species were more rare, ranging between 1 and 11 counts and their densities varied with depth (Table 4 and Figure 4).

Leiopathes sp. occurred in all three study areas and on all substrates except $L$. pertusa thickets (Table 5). The larger sized Leiopathes sp. colonies occurred mostly in areas with large boulders while the smaller sized colonies preferred dead exposed L. pertusa framework. Medium sized colonies occurred both on dead exposed L. pertusa framework and big boulders. Leiopathes sp. species has the largest depth range in the Logachev Province and was the deepest $(874 \mathrm{~m})$ recorded species (Table 4).

Like Leiopathes sp., Parantipathes sp. 1 was found in all three study areas, on all substrates, except for fine sediment. This species occurred mostly on dead exposed L. pertusa framework. Lower occurrences were found on large boulders and fine sediment with pebbles, cobbles, boulders (Table 5). This species had a much narrower depth range of 565-691 m depth (Table 4).

Parantipathes sp. 2 had a similar depth range (Table 4) and substrate preference to Parantipathes sp. 1 and also occurred in all the study areas. The only difference was that this species was also found in fine sediments (Table 5).

Stichopathes cf. gravieri was found in all the studied areas, on three substrates; mostly on large boulders, but also on dead exposed L. pertusa framework and L. pertusa thicket (Table 5). This species had the narrowest depth range and was only found between 663 and $696 \mathrm{~m}$ (Table 4).

Bathypathes sp. occurred mostly in areas with dead exposed L. pertusa framework, but also on large boulders and fine sediment with pebbles, cobbles and boulders (Table 5). This species occurs at greater depths between 678 and $859 \mathrm{~m}$. This species was only found in area 1 and 2 (Table 4).

All four individuals of Antipatharia sp 1 together with one Antipatharia sp. 2 individual were found in one particular location in area 1 with coral rubble (Table 5) as a substrate at $860 \mathrm{~m}$ depth (Table 4).

All three Trissopathes sp. individuals were found within dead exposed L. pertusa framework (Table 5), at a wide depth range of 629-860 $\mathrm{m}$, in area 1 and 2 (Table 4).

Only two records of Acanella sp. were made, one was located in an area with dead exposed coral framework, the other in coral rubble (Table 5). This species was only found at deeper depths of $772 \mathrm{~m}$ (area 2) and $860 \mathrm{~m}$ (area 1) (Table 4).

Seven of the Paramuricea sp. colonies were observed on dead exposed L. pertusa framework, while two were observed in L. pertusa thickets and one in coral rubble (Table 5). This species was found at depths of $546-796 \mathrm{~m}$ in all the study areas (Table 4).

\section{Diversity, Evenness, and Density}

The highest total diversity of non-scleractinian corals was recorded in area 2 , with an $\mathrm{H}^{\prime}$ of 0.40 with a total of eight different species. The SW flank had a higher diversity of non-scleractinian corals compared to the transect on the NW flank. In area 1, a total of nine non-scleractinian coral species were recorded, but the overall $\mathrm{H}^{\prime}$ was slightly lower (0.33), with the $\mathrm{S}$ side of this area being higher in diversity. The lowest number of species and diversity was found in area 3 , with, respectively, six species and an $\mathrm{H}^{\prime}$ of 0.11 . Here, the highest diversity was found on the NW flank (Table 6). After calculating these parameters per area and the mounds' flank, these indices were also calculated per $40 \mathrm{~m}$ transect to reveal more fine-scale spatial variations. An $\mathrm{H}^{\prime}$ of 1.389 and 1.386 were recorded in area 1 at, respectively, 616 and $860 \mathrm{~m}$ depth. In area 2, the highest $\mathrm{H}^{\prime}$ of 1.175 and 1.039 were found at, respectively, 679 and $753 \mathrm{~m}$ depth.

The distribution of the most abundant and therefore dominant species, Leiopathes sp., also differed and affected the evenness on the different mounds. Area 3 had the lowest evenness with a value of 0.06 , followed by area 1 with 0.15 and area 2 with 0.19 . In area 1 an evenness of 1 was found at 616 and $655 \mathrm{~m}$ depth. Area 2 had an evenness of 1 at 663 and $728 \mathrm{~m}$ depth. The evenness in the different areas was always higher on the flanks, where a higher diversity of non-scleractinian species was found (Table 6).

Area 2 had a high average density of non-scleractinian corals with 0.136 ind. $\mathrm{m}^{-2}$. Even though the diversity is low in area 3, it had the highest average densities of non-scleractinian corals $\left(0.143\right.$ ind $\mathrm{m}^{-2}$ ) present, which was predominantly caused by the presence of a high density of Leiopathes sp. Area 1 had the lowest average density of corals present of only 0.034 ind. $\mathrm{m}^{-2}$ (Table 6). The density of non-scleractinian corals was highest on the flanks of the areas, which had a lower diversity and evenness.

As mentioned earlier, the black coral Leiopathes sp. is the most abundant non-scleractinian coral found in the Logachev Province (Table 4). Small sized colonies $(<30 \mathrm{~cm})$ were the most abundant size class, with the highest total density of 9.436 ind. $\mathrm{m}^{-2}$ recorded at depths between 546 and $874 \mathrm{~m}$. Medium sized colonies $(30-100 \mathrm{~cm}$ ) were the least represented, had a density of 0.125 ind. $\mathrm{m}^{-2}$ and were found between 571 and $780 \mathrm{~m}$ depth. Large sized colonies $(>100 \mathrm{~m}$ ) were recorded at depths between 565 and $874 \mathrm{~m}$. The large colonies had their highest densities of 0.364 ind. $\mathrm{m}^{-2}$.

\section{Environmental Drivers of Spatial Variation in Density}

Statistical analyses to identify the environmental variables that cause differences in the density of non-scleractinian species were limited to the two most abundant species; Leiopathes sp. and Parantipathes $\mathrm{sp} 1$. The analyses for Leiopathes $\mathrm{sp}$. was performed for its most abundant size classes (small and large). Due to the small sample size of the remaining species, no significant results were found.

Leiopathes sp.: Percentage cover of dead exposed L. pertusa framework, depth and eastness $(p<0.0001)$ significantly affected the density of small-sized Leiopathes sp. When these variables increase with one unit (respectively percentage per $40 \mathrm{~m}, 40 \mathrm{~m}$, 
TABLE 4 | Observed recorded depth range and density $\left(\mathrm{m}^{-2}\right)$ of non-scleractinian species.

Density $\left(\mathrm{m}^{-2}\right)$

\begin{tabular}{|c|c|c|c|c|c|c|c|c|c|c|c|c|c|}
\hline \multirow[t]{2}{*}{ Species } & \multirow{2}{*}{$\begin{array}{l}\begin{array}{c}\text { Min } \\
\text { depth }\end{array} \\
\text { (m) }\end{array}$} & \multirow{2}{*}{$\begin{array}{c}\text { Max } \\
\text { depth }\end{array}$} & \multirow{2}{*}{$\begin{array}{c}\text { Depth } \\
\text { range } \\
\text { (m) }\end{array}$} & \multirow[t]{2}{*}{ Total } & \multicolumn{3}{|c|}{ Area 1} & \multicolumn{3}{|c|}{ Area 2} & \multicolumn{3}{|c|}{ Area 3} \\
\hline & & & & & & NE & s & & NW & sw & & NE & NW \\
\hline Acanella sp. & 772 & 860 & 88 & 0.013 & 0.022 & 0.000 & 0.030 & 0.018 & 0.000 & 0.000 & 0.001 & 0.034 & 0.000 \\
\hline Antipatharia sp. 1 & 860 & 860 & 0 & 0.025 & 0.087 & 0.000 & 0.120 & 0.000 & 0.000 & 0.000 & 0.002 & 0.000 & 0.000 \\
\hline Antipatharia sp. 2 & 628 & 628 & 0 & 0.006 & 0.000 & 0.000 & 0.000 & 0.000 & 0.022 & 0.000 & 0.000 & 0.000 & 0.000 \\
\hline Leiopathes sp. (large) & 565 & 874 & 309 & 0.364 & 0.152 & 0.078 & 0.181 & 0.090 & 0.989 & 0.448 & 0.009 & 0.000 & 0.070 \\
\hline Leiopathes sp. (medium) & 571 & 780 & 209 & 0.125 & 0.022 & 0.078 & 0.000 & 0.090 & 0.292 & 0.090 & 0.003 & 0.136 & 0.035 \\
\hline Leiopathes sp. (small) & 547 & 874 & 327 & 9.436 & 1.957 & 4.073 & 1.143 & 14.359 & 13.061 & 2.061 & 0.197 & 26.445 & 1.228 \\
\hline Paramuricea sp. & 546 & 796 & 250 & 0.063 & 0.065 & 0.157 & 0.030 & 0.072 & 0.067 & 0.000 & 0.002 & 0.136 & 0.000 \\
\hline Parantipathes sp. 1 & 565 & 691 & 126 & 0.376 & 0.630 & 0.235 & 0.782 & 0.144 & 0.495 & 0.358 & 0.017 & 0.136 & 0.035 \\
\hline
\end{tabular}

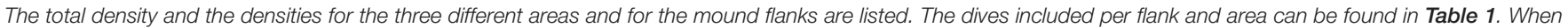

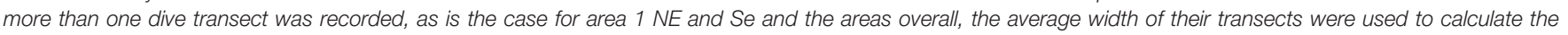
total area covered.

degree per $40 \mathrm{~m}$ ), the density of the colonies increased with, respectively, 2 and $0.8 \%$ and decreased by $48 \%$. For large Leiopathes sp. individuals, only the mixed sediment with large boulders contributed significantly to changes in their density $(p<0.001)$. The density of large Leiopathes sp. individuals increases by $27 \%$ when mixed sediment with large boulders increases $1 \%$ per $40 \mathrm{~m}$. This observation was also clear from the video observations.

Parantipathes sp. 1: Only lithified hardground contributed significantly to changes in the density of Parantipathes sp. 1 $(p<0.01)$. Its density increases $6 \%$ when the percentage cover of lithified hardground increases $1 \%$ per $40 \mathrm{~m}$.

\section{Associated Fauna}

Depending on the speed and height of the ROV, species associated with non-scleractinian corals were not always visible. Therefore, no quantitative data are presented here. Instead, a qualitative overview is given describing which non-scleractinian coral species had associated organisms present, with notes of their location on the coral colonies.

On both small and large sized Leiopathes sp. colonies the anomuran crab Gastroptychus sp. were found on the middle and uppermost outer branches (Figures 5A,B). Small sized colonies would always host one specimen, while larger sized colonies hosted up to three specimens at the same time. On one occasion, a Munida sp. was found sheltering under a small Leiopathes sp. colony (Figure 5H). Ophiuroids and crinoids were only observed on larger sized colonies.

A close-up of a Parantipathes sp. 2 showed a small shrimp in between the branches (Figure 5C). But also Gastroptychus sp. (Figure 5C) and crinoids were found using this species (Figure 5D). On one occasion, a shark egg case was found attached to the top middle branch of a Parantipathes sp. 2 individual (Figure 3C).

One Parantipathes sp. 1 coral had two crinoids attached to the top central branch (Figure 3B). Parantipathes sp. 1 was found carried by three Paromola sp. crabs (Figure 5F). Two crabs were found carrying the plexaurid coral Paramuricea sp. (Figure 5E), ten crabs carried a sponge (Figure 5F), nine carried nothing, and on six occasions, it was unclear whether they were carrying something.

Antipatharia sp. 1 was only found in one location, where large numbers $(\sim 10)$ of crinoids had attached themselves to it, together with one Gastroptychus sp. specimen (Figure 3I).

Finally, Gastroptychus sp. was also found on the top central branch of three Bathypathes sp. individuals (Figure 5G).

One large Paramuricea sp. was observed with a Gorgonocephalus ophiuroid attached to it in the central top branches (Figure $\mathbf{3 H}$ ).

No large megafauna was visible on the corals Acanella sp., Antipatharia sp. 2, Stichopathes cf. gravieri and Trissopathes sp.

\section{DISCUSSION}

A total of ten different non-scleractinian coral species were identified in the ROV video data collected from the Logachev Province, Rockall Bank, NE Atlantic. Of these, eight belonged to the Order Antipatharia (Black corals) and two to the Order Alcyonacea. Even though it is accepted that, like scleractinian corals, non-scleractinian corals prefer areas where high current speeds enhance food availability and where hard substrate is available for settlement (Genin et al., 1986; Thiem et al., 2006; Davies et al., 2009; Roberts et al., 2009), their fine-scale spatial distribution is more complex and both the density and diversity 

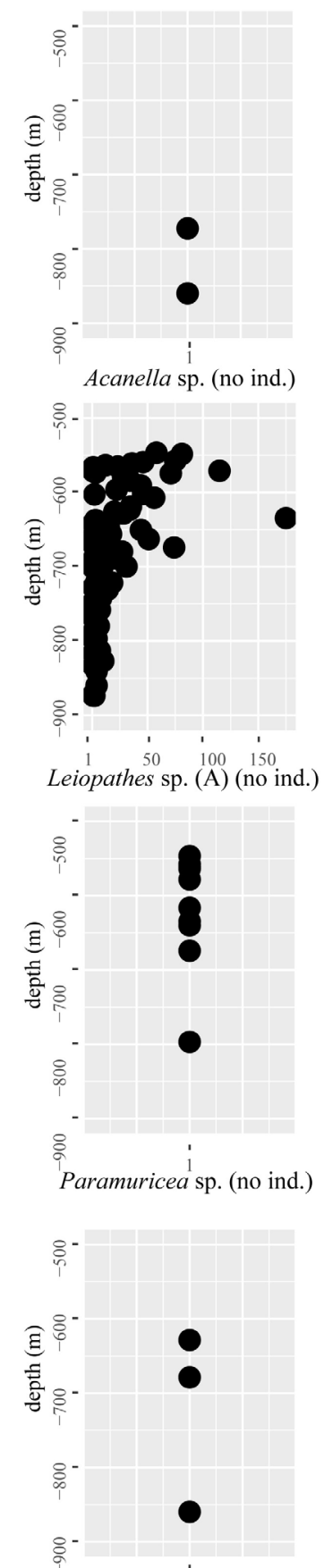

Trissopāthes sp. (no ind.)

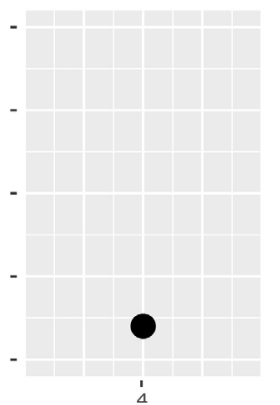

Antipatharia sp. 1 (no ind.)
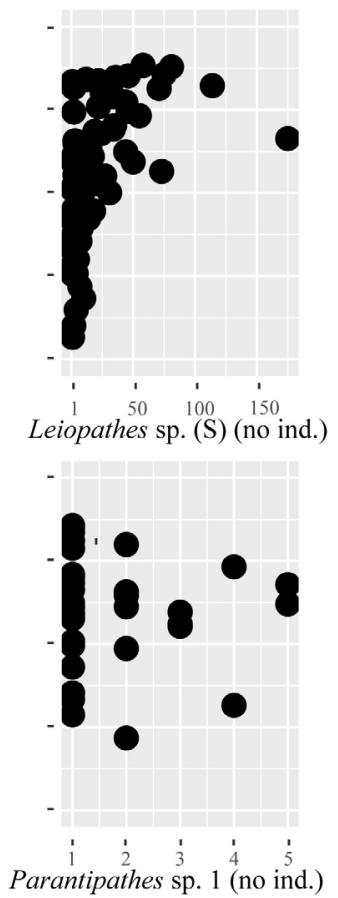

$\stackrel{1}{1} \stackrel{2}{2} \stackrel{3}{3}{ }^{4} \stackrel{5}{5}$

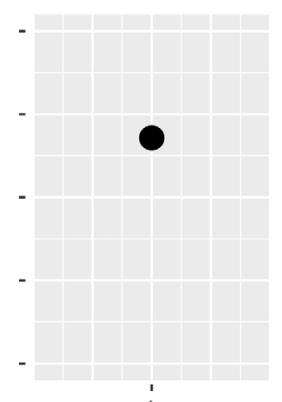

Antipatharia sp. 2 (no ind.)

-

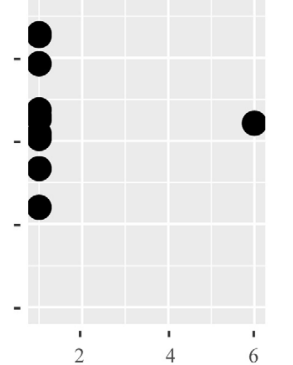

Leiopathes sp. (M) (no ind.)

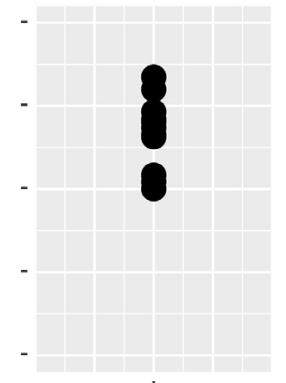

Parantipathes $\stackrel{1}{\mathrm{sp}} 2$ (no ind.)
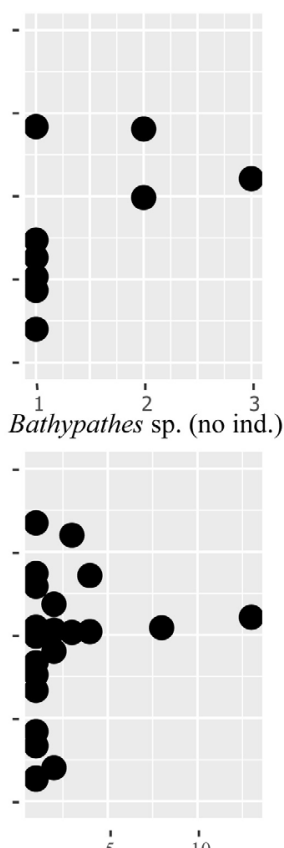

Leiopathes sp. (L) (no ind.)

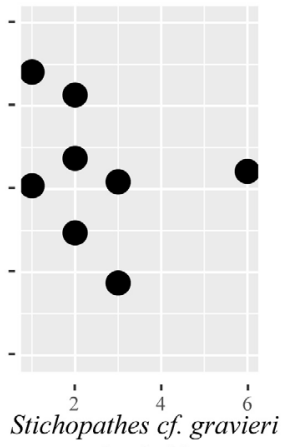

(no ind.)

FIGURE 4 | The number of individuals (no ind.) of a certain species counted in the Logachev Mound Province ( $X$-axis) plotted against depth ( $Y$-axis). This gives an indication of the densities of certain species at certain depths. For Leiopathes sp., the abbreviations A, S, M, and L stand for, respectively, all, small, medium, and large.

of non-scleractinian corals varied within and between the areas examined in this study. It is important to note that it is likely that the depth range of the non-scleractinian corals studied in this area is wider than suggested here, as some could have been overlooked due small colony sizes or poor video quality.
High concentrations of organic matter (mixture of, e.g., dissolved organic matter, bacteria, marine snow, and small zooplankton) which are produced in the photic zone above Rockall bank, can be observed above the Logachev Mound Province, while off-reef seafloor areas at comparable depths are 
TABLE 5 | Number of specimens found by substrate.

\begin{tabular}{|c|c|c|c|c|c|c|c|}
\hline Species & LpT & DEC & CR & LiH & $\mathrm{FS} / \mathrm{P} / \mathrm{C} / \mathrm{B}$ & MS/LB & FS \\
\hline Acanella sp. (2 ind.) & 0 & 1 & 1 & 0 & 0 & 0 & 0 \\
\hline Antipatharia sp. 1 (4 ind.) & 0 & 0 & 4 & 0 & 0 & 0 & 0 \\
\hline Antipatharia sp. 2 (1 ind.) & 0 & 0 & 1 & 0 & 0 & 0 & 0 \\
\hline Bathypathes sp. (13 ind.) & 0 & 11 & 1 & 0 & 2 & 3 & 1 \\
\hline Leiopathes sp. (all) (1583 ind.) & 0 & 2201 & 50 & 3 & 23 & 69 & 12 \\
\hline Leiopathes sp. (large) (58 ind.) & 0 & 8 & 2 & 0 & 1 & 49 & 3 \\
\hline Leiopathes sp. (medium) (20 ind.) & 0 & 12 & 0 & 1 & 1 & 11 & 0 \\
\hline Leiopathes sp. (small) (1505 ind.) & 0 & 2181 & 48 & 2 & 21 & 9 & 9 \\
\hline Paramuricea sp. (10 ind.) & 2 & 7 & 1 & 0 & 0 & 0 & 0 \\
\hline Parantipathes sp. 1 (60 ind.) & 3 & 50 & 2 & 1 & 5 & 4 & 0 \\
\hline Parantipathes sp. 2 (11 ind.) & 0 & 13 & 0 & 0 & 1 & 1 & 2 \\
\hline Stichopathes cf. gravieri (20 ind.) & 2 & 9 & 0 & 0 & 0 & 12 & 0 \\
\hline Trissopathes sp. (3 ind.) & 0 & 3 & 0 & 0 & 0 & 0 & 0 \\
\hline
\end{tabular}

TABLE 6 | The diversity, evenness, average density, and number of different species counted per area and mound flank.

\begin{tabular}{lcccc}
\hline Area & Diversity $\left.\mathbf{( H}^{\prime}\right)$ & Evenness & Density (ind. $\mathbf{~}^{-\mathbf{2}}$ ) & No. species \\
\hline $\mathbf{1}$ & $\mathbf{0 . 3 3}$ & $\mathbf{0 . 1 5}$ & $\mathbf{0 . 0 3 4}$ & $\mathbf{9}$ \\
$1 \mathrm{NE}$ & 0.29 & 0.26 & 0.046 & 3 \\
$1 \mathrm{~S}$ & 1.48 & 0.67 & 0.028 & 9 \\
$\mathbf{2}$ & $\mathbf{0 . 4 0}$ & $\mathbf{0 . 1 9}$ & $\mathbf{0 . 1 3 6}$ & $\mathbf{8}$ \\
$2 \mathrm{NW}$ & 0.38 & 0.18 & 0.155 & 8 \\
$2 \mathrm{SW}$ & 0.67 & 0.48 & 0.032 & 4 \\
$\mathbf{3}$ & $\mathbf{0 . 1 1}$ & $\mathbf{0 . 0 6}$ & $\mathbf{0 . 1 4 3}$ & $\mathbf{6}$ \\
$3 \mathrm{NE}$ & 0.14 & 0.07 & 0.270 & 6 \\
$3 \mathrm{NW}$ & 0.49 & 0.35 & 0.014 & 4 \\
\hline
\end{tabular}

depleted in suspended organic matter (Duineveld et al., 2007; Soetaert et al., 2016). When scleractinian cold-water corals, like L. pertusa and M. oculata, form mounds of a certain size, they can engineer the environment by altering the local hydrodynamics to their benefit. The clustered Logachev coldwater coral carbonate mounds have reached this size, and therefore induce tidal up- and downwelling, internal waves, and as a consequence also large INL, which supply the corals together with other filter feeders in their community with food (Mienis et al., 2007; Soetaert et al., 2016). This increased concentration of organic matter was reflected through healthy dense live L. pertusa thickets on the summits of the clustered mounds in our study area at a relatively shallow depth (between 560 and $610 \mathrm{~m}$ depth). These areas coincided with low densities and diversity of non-scleractinian corals even though this is precisely where organic matter concentrations are the highest (Soetaert et al., 2016). There are two explanations for this observation. Firstly, the permanent mucus layer (coenosarc) on the skeleton of live scleractinian corals prevents attachment of most epibiotic species (Freiwald, 2002; Buhl-Mortensen et al., 2010). Secondly, in our study area, the scleractinian corals might outcompete other filter and suspension feeders for food on mound summits. The food capture rates for different species can strongly depend on current velocity, seawater temperature and polyp size. High flow velocities can deform coral polyps reducing the exposed feeding surface area (Dai and Lin, 1993; Purser et al., 2010; Wijgerde et al., 2012; Gori et al., 2015). Higher flow speeds may also make the polyps less efficient at holding prey (Sebens et al., 1998; Orejas et al., 2011). Colder temperatures may cause the polyps to contract or affect nematocyst function (Gori et al., 2015). Warmer temperatures may increase the metabolism of corals, but can cause starvation if food supply is not met (Dodds et al., 2007; Davies et al., 2009). Some coral species with larger polyps can remove particles from their environment more efficiently compared to those with smaller polyps (Porter, 1976; Palardy et al., 2005; Wang et al., 2012). The effect of flow velocity, temperature and polyp size are unknown for the non-scleractinian corals described in this study. Since food supply is essential to maintain the basic physiological processes (Naumann et al., 2011), understanding what affects coral food capturing rates may help to explain the distribution pattern of the non-scleractinian corals in the Logachev Mound Province.

Dead exposed L. pertusa framework, and coral rubble become more abundant with increasing depth as the concentration of fresh organic matter decreases, and food becomes scarce toward deeper waters (Kenyon et al., 2003). Consequently, the first peak in non-scleractinian diversity was observed, right below the L. pertusa thickets in area 1. Food supply will still be relatively high at these depths, and an increased range of substrates such as coral rubble, dead L. pertusa framework and hard substrates (lithified hardgrounds, pebbles, cobbles, boulders) become available and can be used as settlement substrates (Mortensen and Fosså, 2006; Buhl-Mortensen et al., 2010). A significant correlation was found between lithified hardgrounds and the density of Parantipathes sp. Only a small percentage $(22 \%)$ of the substrates in the study area consisted of these hardgrounds, but they are an important aspect of overall mound growth and development as they provide stability to the steep slopes of the mounds and can be used as substratum for mound-building invertebrates (Noé et al., 2006). Hardgrounds on the coral carbonate mounds 


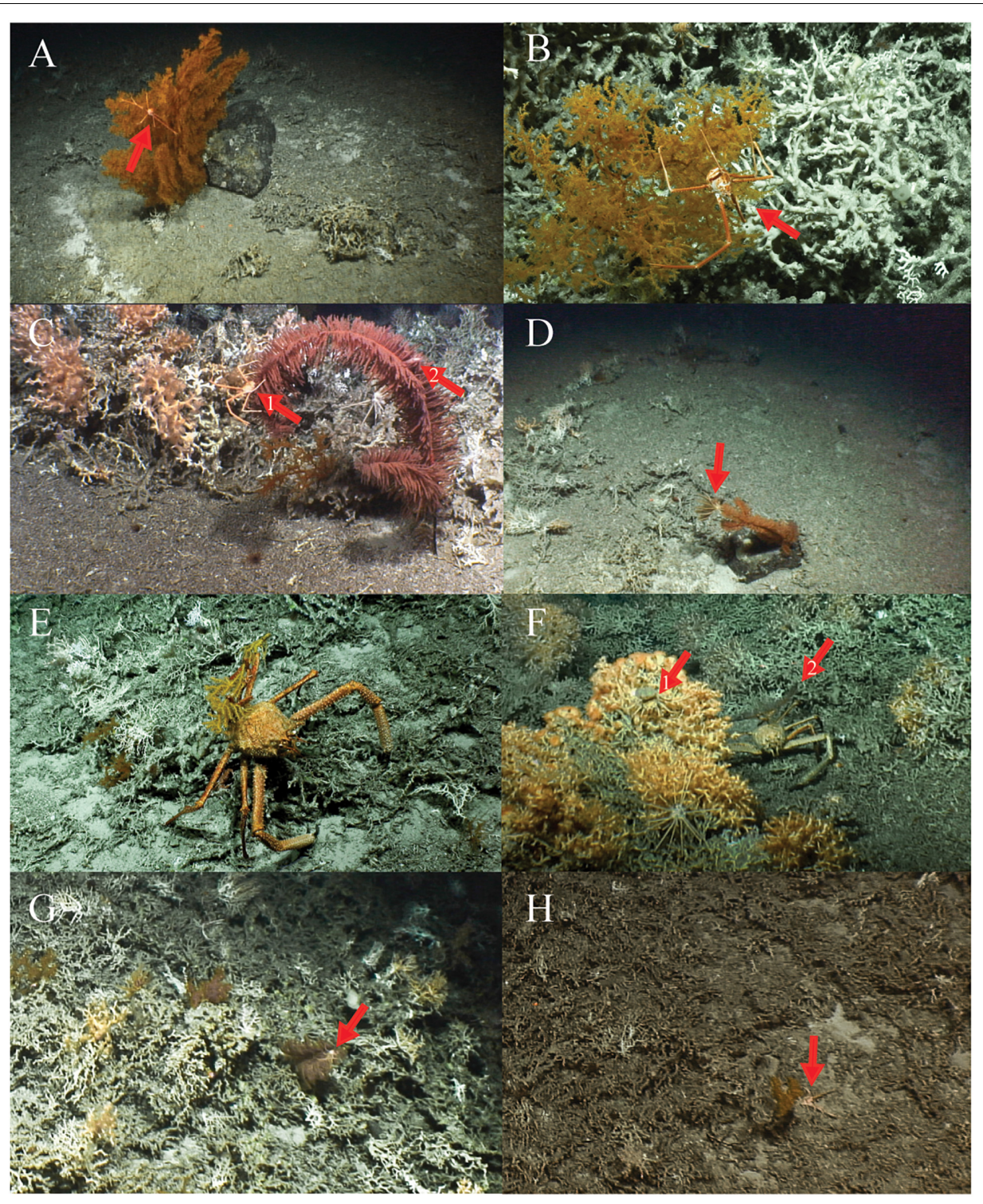

FIGURE 5 | (A,B) large and small-sized Leiopathes sp. colonies with the arrow pointing to a Gastroptychus sp. (C) Parantipathes sp. 2 with the first arrow pointing to a Gastroptychus sp. and the second arrow to a small shrimp. (D) Parantipathes sp. 2 with the arrow pointing to an attached crinoid. (E) Paramuricea sp. carried by Paromola cuvieri. (F) The first arrow points to Paromola cuvieri carrying a sponge and the second arrow points to Paromola cuvieri carrying a Parantipathes sp. 1. (G) The arrow points to a Gastroptychus sp. on the top central branch of Bathypathes sp. (H) The arrow points to Munida sp. sheltering under a small Leiopathes sp. colony.

in the Rockall area have been identified in the past (Van Weering et al., 2003). These hardgrounds can be completely exposed, showing signs of erosion by currents and sponge borings or can have different degrees of sediment cover with live and dead coral colonies (Wheeler et al., 2005, 2007). The exposure of these hardgrounds is associated with strong bottom currents (Noé et al., 2006), which could mean an increase in the food-encounter rate for cold-water corals that were able to settle there.

Differences observed in densities of non-scleractinian corals could be related to local variations in food supply. Soetaert et al. (2016) model's output of vertical current velocities and organic matter concentration in the water column of the Logachev Mound Province, appears to suggest that mounds that are located closer to Rockall Bank access more optimal food and hydrodynamic conditions. Therefore, the distance of the studied areas from the shallow bank to the deeper located mounds could affect the concentration of the organic matter reaching the corals. The lowest diversity and highest density of nonscleractinian corals was calculated for area 3. Even though the nutritional quality may not be so good, NLs could be an additional source of food, which could explain why we see high densities in area 3, which is located approximately $\sim 25 \mathrm{~km}$ from the bank (Mienis et al., 2007). From both shallow water 
and land based ecosystems it is known that higher nutrient input can lead to a lower diversity and higher density for a rather low number of species (Hector et al., 1999; Chapin et al., 2000; Wiedenmann et al., 2013). This would suggest that area 3 is receiving higher concentrations of organic matter. The flanks of the areas with higher densities of corals were located perpendicular to the SW orientated residual current. It is likely that this current also facilitates the supply of additional food sources.

The most abundant non-scleractinian coral in our study areas is Leiopathes sp. Our data showed that Leiopathes sp. occupied all available substrates. From this observation, it seems this species is a generalist for settlement substrates, this could explain why it thrives in all our studied areas, even when the range of available substrates is low. Leiopathes sp. has a slow radial growth rate of $0.005-0.022 \mathrm{~mm} \mathrm{yr}^{-1}$ and is one of the longest living species on earth (Roark et al., 2009; Carreiro-Silva et al., 2013). The slower radial growth rates and their longevity might be of an advantage in areas where food supply is scarcer.

An interesting difference in the density of the various size classes of Leiopathes sp. was observed. The vast majority (95\%) of the colonies in our area were small sized $(>30 \mathrm{~cm})$, while $1 \%$ was medium $(30-100 \mathrm{~cm})$ and $4 \%$ were large $(>100 \mathrm{~cm})$. A high density of small-sized colonies could indicate a successful dispersal event with a high survival rate after settlement or that they are growing from regenerating fragments (Molodtsova, 2011). However, substrate stability might be another factor influencing the distribution of the different size classes. Small sized colonies were found in areas with dead exposed L. pertusa framework (95\% of total individuals), while the large sized colonies were mainly found in areas with large boulders (78\% of total individuals). Medium sized colonies were found in similar densities on both substrates. We suggest that this difference in survival could be related to the stability large boulders provide to a large colony. Colonies growing on dead exposed L. pertusa framework are inclined to fall over when exposed to high current speeds. Toward the summit of the cold-water coral mounds, large boulders become rare as they are covered with live and dead $L$. pertusa and therefore are unavailable as a stable substrate for large-sized Leiopathes sp. colonies. Therefore, the higher percentage cover of dead exposed $L$. pertusa framework versus large boulders could also explain why a difference in the densities of the different size classes is observed.

In past studies as well as here, shrimps, crabs, crinoids and ophiuroids were found to be using non-scleractinian coral species as a feeding platform and a place to shelter (e.g., Vytopil and Willis, 2001; Burkepile and Hay, 2007; De Clippele et al., 2015). No associates were observed visually on the corals Acanella sp., Antipatharia sp. 2, Stichopathes cf. gravieri, Trissopathes sp. and only one observation was made for the plexaurid Paramuricea sp. For Paramuricea sp. this was surprising as it has been found occupied abundantly by megafauna elsewhere (Rosenberg et al., 2005; De Clippele et al., 2015). Higher numbers of organisms occupied non-scleractinian coral colonies that were larger. This is expected as smaller sized colonies are unable to have more than one organism attached due to competition for perch sites. These associated organisms were mainly located on the top outer parts of the colonies, which increases their food encounter rate as their elevated position is further away from the slower current in the near-bottom boundary and therefore closer to the main flow (Fujita and Ohta, 1988). Generally, it is the corals' size, the number of branches and the availability of sufficient food that will impact the presence of associates on colonies. On one occasion, the squat lobster Munida sp. was found sheltering under a small Leiopathes sp. colony. This behavior was also observed under the sea pen Kophobelemnon stelliferum (De Clippele et al., 2015).

Even though non-scleractinian corals function as a habitat, only a minority of them had associated fauna present. This low occurrence of associated fauna could be caused by the lack of detailed surveying in our study, the high flexibility of the coral branches, and the relatively low availability of large-sized colonies. The non-scleractinian corals in our study have a more flexible skeleton compared to, e.g., the gorgonian Paragorgia arborea which commonly has abundant associated fauna present (Buhl-Mortensen and Mortensen, 2004, 2005; De Clippele et al., 2015). The skeleton of black corals is more flexible and chitinous, which is an adaptation for living in areas with very strong currents. To withstand strong currents, $P$. arborea grows much thicker branches compared to other corals (Mortensen and BuhlMortensen, 2004) which provide the associated organisms with a more robust and larger surface area to inhabit. A negative relationship between the presence of associated fauna and the flexibility and size of the colonies and branches has been shown before and therefore explains our lower presence of these associates (Buhl-Mortensen and Mortensen, 2004; Santavy et al., 2013).

Aside from functioning as a feeding platform and as a shelter, non-scleractinian corals were also used by the carrier crab Paromola cuvieri as camouflage or more likely, as anti-predator defense. In total, 30 carrier crabs were observed in this study, of which most were carrying a sponge, but also the black coral species, Parantipathes sp. 1 and the plexaurid Paramuricea sp. Antipatharians and alcyonaceans have previously been reported being carried by $P$. cuvieri between the dactyls and propodi of the fifth pereiopods (Wicksten, 1985; Guinot et al., 1995; Weaver et al., 2009; Braga-Henriques et al., 2012). BragaHenriques et al. (2012) studied the behavior of 16 carrier crabs (P. cuvieri) in the Azores. The Braga-Henriques et al. (2012) study observed that damage of the fifth pereiopods could be a reason for when there was no object being carried. In the study presented here, no damage was observed, but this could be related to the distance between the ROV and seabed limiting the resolution of the video. The species that are carried by $P$. cuvieri varies depending on what species are available in the surrounding habitat. However, it will not necessarily be the most common invertebrates in that habitat (Braga-Henriques et al., 2012). The selection process of which species is carried is still unclear but is possibly related to weight, size and palatability (Braga-Henriques et al., 2012). In the Azores study, and in this study, camouflage-type behavior 
was observed, as in some occasions the crab would lift the object above their carapace when disturbed by the ROV and its lights. However, Capezzuto et al. (2012) only observed such behavior as an adaptation to an anti-predator defense. At present, there are no indications of $P$. cuvieri using the carried species to attract other crabs or species. The sponges and cnidarians can distract predators, but also can protect the crabs with spicules and secondary metabolites against predators (Coll et al., 1982; Hill and Hill, 2002; Barsby and Kubanek, 2005; Hill et al., 2005).

\section{CONCLUSION}

Amongst the clusters of cold-water coral carbonate mounds, differences in the diversity and density of non-scleractinian corals were observed. In this study, the balance between food supplied by intermediate nepheloid layers and tidal downwelling, together with the presence of $L$. pertusa thickets and a variety of substrates seem to affect the diversity and density patterns observed. Substrate availability and stability is an important contributor to the differences observed in diversity and density, but also for the size class distribution of Leiopathes sp. The explanations that are given here for the differences in the fine-scale spatial distribution of non-scleractinian corals remain speculative. To fill in the gaps in our knowledge, more information on their ecophysiology and specific local organic matter concentrations for each area are needed.

\section{REFERENCES}

Althaus, F., Williams, A., Schlacher, T. A., Kloser, R. J., Green, M. A., Barker, B. A., et al. (2009). Impacts of bottom trawling on deep-coral ecosystems of seamounts are long-lasting. Mar. Ecol. Prog. Ser. 397, 279-294. doi: 10.3354/ meps08248

Andrews, A. H., Cordes, E. E., Mahoney, M. M., Munk, K., Coale, K. H., Cailliet, G. M., et al. (2001). Age and growth of a deep-sea, habitat-forming octocorallian (Primnoa sp.) from the gulf of Alaska, with radiometric age validation. Hydrobiologia 471, 101-110. doi: 10.1023/A:1016501 320206

Andrews, A. H., Stone, R. P., Lundstorm, C. C., and DeVogelaere, A. P. (2009). Growth rate and age determination of bamboo corals from the norteastern Pacific Ocean using refined 210Pb dating. Mar. Ecol. Prog. Ser. 397, 173-185. doi: $10.3354 /$ meps08193

Barsby, T., and Kubanek, J. (2005). Isolation and structure elucidation of feeding deterrent diterpenoids from the sea pansy, Renilla reniformis. J. Nat. Prod. 68, 511-516. doi: 10.1021/np049609u

Braga-Henriques, A., Carreiro-Silva, M., Tempera, F., Porteiro, F. M., Jakobsen, K., Jakobsen, J., et al. (2012). Carrying behavior in the deep-sea crab Paromola cuvieri (Northeast Atlantic). Mar. Biodiver. 42, 37-46. doi: 10.1007/s12526-0110090-3

Buhl-Mortensen, L., and Mortensen, P. B. (2004). Crustaceans associated with the deep-water gorgonian corals Paragorgia arborea (L., 1758) and Primnoa resedaeformis (Gunn., 1763). J. Nat. Hist. 38, 1233-1247. doi: 10.1007/s125260110090-3

Buhl-Mortensen, L., and Mortensen, P. B. (2005). Distribution and Diversity of Species Associated With Deep-Sea Gorgonian Corals off Atlantic Canada, Cold-water Corals and Ecosystems. Berlin: Springer-Verlag, 849-879.

Buhl-Mortensen, L., Vanreusel, A., Gooday, A. J., Levin, L. A., Preide, I. G., Buhl-Mortensen, P., et al. (2010). Biological structures as a source of habitat

\section{AUTHOR CONTRIBUTIONS}

LDC collected and analyzed the data. VH and JR supervised the study and reviewed the manuscript. TM identified the black corals and reviewed the manuscript.

\section{FUNDING}

The ROV multibeam bathymetry used in this study was gathered through the UK Ocean Acidification Research Programme benthic consortium (NERC grant NE/H017305/1). LDC was funded both by the EU Horizon 2020 ATLAS project (Grant No. 678760) and by a Heriot-Watt University James Watt studentship. JR also received funding from the EU Horizon 2020 research and innovation programme under grant agreement no. 678760 (ATLAS). This manuscript reflects the authors' view alone, and the European Union cannot be held responsible for any use that may be made of the information contained herein. $\mathrm{VH}$ was funded by the ERC Starting Grant project CODEMAP (Grant No. 258482). TM was funded by RF State Assignment (0149-2019-0009).

\section{ACKNOWLEDGMENTS}

We thank the captain and the crew of the RRS James Cook for assistance at sea.

heterogeneity and biodiversity on the deep ocean margins. Mar. Ecol. Evol. Pers. 31, 21-50. doi: 10.1111/j.1439-0485.2010.00359.x

Burkepile, D. E., and Hay, M. E. (2007). Predator release of the gastropod Cyphoma gibbosum increases predation on gorgonian corals. Oecologia 154, 167-173. doi: 10.1007/s00442-007-0801-4

Cairns, S. D. (2007). Deep Water Corals: An overview with special reference to diversity and distribution of deep water scleractinian corals. Bull. Mar. Sci. 81, 311-322.

Capezzuto, F., Maiorano, P., Indennidate, A., and Sion, L. (2012). Occurrence and behaviour of Paromola cuvieri (Crustacea, Decapoda) in the Santa Maria di Leuca cold-water coral community (Mediterranean Sea). Deep Sea Res. I 59, 1-7. doi: 10.1016/j.dsr.2011.10.006

Carreiro-Silva, M., Andrews, A. H., Braga-Henriques, A., De Matos, V., Porteiro, F. M., and Santos, R. S. (2013). Variability in growth rates of long-lived black coral Leiopathes sp. from the Azores. Mar. Ecol. Prog. Ser. 473, 189-199. doi: 10.3354/meps10052

Cerrano, C., Danovaro, R., Gambi, C., Pusceddu, A., Riva, A., and Schiaparelli, S. (2010). Gold coral (Savalia savaglia) and gorgonian forests enhance benthic biodiversity and ecosystem functioning in the mesophotic zone. Biodivers. Conserv. 19, 153-167. doi: 10.1007/s10531-0099712-5

Chapin, F. S. III, Zavaleta, E. S., Eviner, V. T., Naylor, R. L., Vitousek, P. M., Reynolds, H. L., et al. (2000). Consequences of changing biodiversity. Nature 405:234. doi: 10.1038/35012241

Clarke, K. R., and Warwick, R. M. (2001). Change in Marine Communities: an Approach to Statistical Analysis and Interpretation, 2nd Edn. Cambridge: National Environment Research Council.

Cnaan, A., Laird, N. M., and Slasor, P. (1997). Tutorial in biostatistics: using the general linear mixed model to analyse unbalanced repeated measures and longitudinal data. Stat. Med. 16:80. doi: 10.1002/(SICI)10970258(19971030)16:20<2349::AID-SIM667>3.0.CO;2-E 
Coll, J. C., La Barre, S., Sammarco, P. W., Williams, W. T., and Bakus, G. J. (1982). Chemical defences of soft corals (Coelenterata: Octocorallia) of the great barrier reef: a study of comparative toxicities. Mar. Ecol. Progr. Ser. 8, 271-278. doi: $10.3354 /$ meps008271

Corbera Pascual, G. (2015). The Role of Gorgonians as Engineering Species, in the Structure and Diversity of Benthic Communities. Ms Thesis, Faculty of natural and environmental sciences, oceans and earth sciences, University of Southampton, Southampton.

Cúrdia, J., Carvalho, S., Pereira, F., Guerra-García, J. M., Santos, M. N., and Cunha, M. R. (2015). Diversity and abundance of invertebrate epifaunal assemblages associated with gorgonians are driven by colony attributes. Coral Reefs 34, 611-624. doi: 10.1007/s00338-015-1283-1

Cyr, F., Van Haren, H., Mienis, F., Duineveld, G., and Bourgault, D. (2016). On the influence of cold-water coral mound size on flow hydrodynamics, and vice versa. Geophys. Res. Lett. 43, 775-783. doi: 10.1002/2015GL067038

Dai, C. F., and Lin, M. C. (1993). The effects of flow on feeding of three gorgonians from southern Taiwan. J. Exp. Mar. Biol. 173, 57-69. doi: 10.1016/00220981(93)90207-5

Davies, A. J., Duineveld, G. C., Lavaleye, M. S. S., Bergman, M. J. N., Van Haren, H., and Roberts, J. M. (2009). Downwelling and deep-water bottom currents as food supply mechanisms to the cold-water coral Lophelia pertusa (Scleractinia) at the mingulay reef complex. Limnol. Oceanogr. 54, 620-629. doi: 10.4319/lo.2009.54. 2.0620

De Clippele, L. H., Buhl-Mortensen, P., and Buhl-Mortensen, L. (2015). Fauna associated with cold water gorgonians and sea pens. Cont. Shelf Res. 105, 67-78. doi: 10.1016/j.csr.2015.06.007

De Clippele, L. H., Gafeira, J., Robert, K., Hennige, S., Lavaleye, M. S., Duineveld, G. C. A., et al. (2017). Using novel acoustic and visual mapping tools to predict the small-scale spatial distribution of live biogenic reef framework in cold-water coral habitats. Coral Reefs 36, 255-268. doi: 10.1007/s00338-016-1519-8

de Haas, H., Mienis, F., Frank, N., Richter, T. O., Steinacher, R., de Stigter, H., et al. (2009). Morphology and sedimentology of (clustered) cold-water coral mounds at the south Rockall Trough margins, NE Atlantic Ocean. Facies 55, 1-26. doi: 10.1007/s10347-008-0157-1

Dobson, A. J., and Barnett, A. G. (2008). Introduction to Generalized Linear Models, 3rd Edn. Boca Raton, FL: Chapman and Hall.

Dodds, L. A., Roberts, J. M., Taylor, A. C., and Marubini, F. (2007). The cold-water coral Lophelia pertusa (Scleractinia) reveals metabolic tolerance to temperature and dissolved oxygen change. J. Exp. Mar. Biol. Ecol. 349, 205-214. doi: 10.1016/ j.jembe.2007.05.013

Dorschel, B., Hebbeln, D., Foubert, A., White, M., and Wheeler, A. J. (2007). Hydrodynamics and cold-water coral facies distribution related to recent sedimentary processes at Galway Mound west of Ireland. Mar. Geol. 244, 184-195. doi: 10.1016/j.margeo.2007.06.010

Duineveld, G. C. A., Lavaleye, M. S. S., Bergman, M. J. N., de Stigter, H., and Mienis, F. (2007). Trophic structure of a cold-water coral mound community (Rockall Bank, NE Atlantic) in relation to the near-bottom particle supply and current regime. Bull. Mar. Sci. 81, 449-467.

Etnoyer, P., and Morgan, L. E. (2005). Occurrences of Habitat-Forming, Deep-Sea Corals in the Northeast Pacific. Final Report NOAA Off Protected Resources. Seattle: Marine Conservation Biology Institute.

Findlay, H. S., Artioli, Y., Moreno Navas, J., Hennige, S. J., Wicks, L. C., Huvenne, V. A. I., et al. (2013). Tidal downwelling and implications for the carbon biogeochemistry of cold-water corals in relation to future ocean acidification and warming. Glob. Change Biol. 19, 2708-2719. doi: 10.1111/gcb. 12256

Freiwald, A. (2002). "Reef-forming cold-water corals," in Ocean Margin Systems, eds G. Wefer, D. Billett, D. Hebbeln, B. B. Jorgensen, M. Schluter, and T. van Weering (Berlin: Springer), 365-385. doi: 10.1007/978-3-662-05127-6_23

Fujita, T., and Ohta, S. (1988). Photographic observations of the life-style of a deepsea ophiuroid Asteronyx loveni (Echinodermata). Deep Sea Res. Part Oceanogr. Res. Papers 35, 2029-2043. doi: 10.1016/0198-0149(88)90123-9

Fuller, S. D., Murillo Perez, F. J., Wareham, V., and Kenchington, E. (2008). Vulnerable Marine Ecosystems Dominated by Deep-Water Corals and Sponges in the NAFO Convention Area, Serial No N5524. Nova Scotia: NAFO.

Genin, A., Dayton, P. K., Lonsdale, P. F., and Spiess, F. N. (1986). Corals on seamount peaks provide evidence of current acceleration over deep-sea topography. Nature 322:59. doi: 10.1038/322059a0
Gori, A., Reynaud, S., Orejas, C., and Ferrier-Pagès, C. (2015). The influence of flow velocity and temperature on zooplankton capture rates by the cold-water coral Dendrophyllia cornigera. J. Exp. Mar. Biol. Ecol. 466, 92-97. doi: 10.1016/ j.jembe.2015.02.004

Grigg, R. W. (2001). Black coral: history of a sustainable fishery in Hawaii. Pacif. Sci. 55, 191-299. doi: 10.1353/psc.2001.0022

Guinan, J., Brown, C., Dolan, M. F. J., and Grehan, A. J. (2009). Ecological niche modelling of the distribution of cold-water coral habitat using underwater remote sensing data. Ecol. Inform. 4, 83-92. doi: 10.1016/j.ecoinf.2009.01.004

Guinot, D., Doumenc, D., and Chintiroglou, C. C. (1995). A review of the carrying behaviour in Brachyuran crabs, with additional information on the symbioses with sea anemones. Raff. Bull. Zool. 43, 377-416.

Hector, A., Schmid, B., Beierkuhnlein, C., Caldeira, M. C., Diemer, M., Dimitrakopoulos, P. G., et al. (1999). Plant diversity and productivity experiments in European grasslands. Science 286, 1123-1127. doi: 10.1126/ science.286.5442.1123

Henry, L. A., Davies, A. J., and Roberts, J. M. (2010). Beta diversity of coldwater coral reef communities off western Scotland. Coral Reefs 29, 427-436. doi: 10.1007/s00338-009-0577-6

Henry, L.-A., Frank, N., Hebbeln, D., Wienberg, C., Robinson, L., van de Flierdt, T., et al. (2014). Global ocean conveyor lowers extinction risk in the deep sea. Deep Sea Res. Part I 88, 8-16. doi: 10.1016/j.dsr.2014.03.004

Henry, L. A., and Roberts, J. M. (2007). Biodiversity and ecological composition of macrobenthos on cold-water coral mounds and adjacent off-mound habitat in the bathyal Porcupine Seabight, NE Atlantic. Deep Sea Res. Part I Oceanogr. Res. Papers 54, 654-672. doi: 10.1016/j.dsr.2007.01.005

Hill, M. S., and Hill, A. L. (2002). Morphological plasticity in the tropical sponge Anthosigmella varians: responses to predators and wave energy. Biol. Bull. 202, 86-95. doi: 10.2307/1543225

Hill, M. S., Lopez, N. A., and Young, K. A. (2005). Anti-predator defences in western North Atlantic sponges with evidence of enhanced defence through interactions between spicules and chemicals. Mar. Ecol. Prog. Ser. 291, 93-102. doi: 10.3354/meps291093

Hill, T. M., Spero, H. J., Guilderson, T., LaVigne, M., Clague, D., Macalello, S., et al. (2011). Temperature and vital effect controls on bamboo coral (Isididae) isotope geochemistry: A test of the "lines method.". Geochem. Geophys. Geosyst. 12, 1-14. doi: 10.1029/2010GC003443

Holliday, N. P., Pollard, R. T., Read, J. F., and Leach, H. (2000). Water mass properties and fluxes in the Rockall Trough, 1975-1998. Deep Sea Res. Part I Oceanogr. Res. Papers 47, 1303-1332. doi: 10.1016/S0967-0637(99)00109-0

Huthnance, J. M. (1986). The Rockall slope current and shelf-edge processes. Proc. R. Soc. Edinburgh 88B, 83-101. doi: 10.1017/S0269727000004486

Kenyon, N. H., Akhmetzhanov, A. M., Wheeler, A. J., van Weering, T. C. E., de Haas, H., and Ivanov, M. K. (2003). Giant carbonate mud mounds in the southern Rockall Trough. Mar. Geol. 195, 5-30. doi: 10.1016/S0025-3227(02) 00680-1

Lacharite, M., and Metaxas, A. (2013). Early life history of deep-water gorgonian corals may limit their abundance. PLoS One 8:e65394. doi: 10.1371/journal. pone. 0065394

Le Guilloux, E., Hall-Spencer, J. M., Söffker, M. K., and Olu, K. (2010). Association between the squat lobster Gastroptychus formosus and cold-water corals in the North Atlantic. J. Mar. Biol. Assoc. U.K. 90, 1363-1369. doi: 10.1017/ s0025315410000524

Madsen, F. J. (1956). Primnoella krampi n. sp. a new deep-sea octocoral. Galathea Rep. 2, 21-22.

McCullagh, P., and Nelder, J. (1989). Generalized Linear Models, 2nd Edn. Boca Raton: Chapman and Hall. doi: 10.1007/978-1-4899-3242-6

Mienis, F., de Stigter, H. C., White, M., Duineveld, G., de Haas, H., and van Weering, T. C. E. (2007). Hydrodynamic controls on cold-water coral growth and carbonate-mound development at the SW and SE Rockall Trough Margin, NE Atlantic Ocean. Deep Sea Res. I 54, 1655-1674. doi: 10.1016/j.dsr.2007.05. 013

Mienis, F., van de Land, C., de Stigter, H. C., van de Vorstenbosch, M., de Haas, H., Richter, T., et al. (2009). Sediment accumulation on a cold-water carbonate mound at the Southwest Rockall Trough margin. Mar. Geol. 265, 40-50. doi: 10.1016/j.margeo.2009.06.014

Mienis, F., van Weering, T., de Haas, H., de Stigter, H., Huvenne, V. A. I., and Wheeler, A. (2006). Carbonate mound development at the SW Rockall Trough 
margin based on high resolution TOBI and seismic recording. Mar. Geol. 233, 1-4. doi: 10.1016/j.margeo.2006.08.003

Milne-Edwards, H., and Haime, J. (1857). Histoire Naturelle des Coralliaires ou Polypes Proprement Dits. Paris: Librairie Encyclopédique de Roret.

Molodtsova, T. N. (2011). A new species of Leiopathes (Anthozoa: Antipatharia) from the great Meteor seamount (North Atlantic). Zootaxa 3138, 52-64. doi: 10.11646/zootaxa.3138.1.3

Mortensen, P., and Fosså, J. H. (2006). "Species diversity and spatial distribution of invertebrates on deep water Lophelia reefs in Norway," in Proceedings of 10th International Coral reef symposium, Okinawa, 1849-1868.

Mortensen, P. B., and Buhl-Mortensen, L. (2004). Distribution of deep-water gorgonian corals in relation to benthic habitat features in the Northeast channel (Atlantic Canada). Mar. Biol. 144, 1223-1238. doi: 10.1007/s00227-003-1280-8

Mortensen, P. B., Hovland, M., Brattegard, T., and Farestveit, R. (1995). Deep water bioherms of the scleractinian coral Lophelia pertusa (L.) at $64^{\circ} \mathrm{N}$ on the Norwegian shelf: structure and associated mega- fauna. Sarsia 80, 145-158. doi: 10.1080/00364827.1995.10413586

Naumann, M. W., Orejas, C., Wild, C., and Ferrier-Pages, C. (2011). First evidence for zooplankton feeding sustaining key physiological processes in a scleractinian cold-water coral. J. Exp. Biol. 214, 3570-3576. doi: 10.1242/jeb. 061390

Noé, S., Titschack, J., Freiwald, A., and Dullp, W.-C. (2006). From sediment to rock: diagenetic processes of hardground formation in deep-water carbonate mounds of the NE Atlantic. Facies 52, 183-208. doi: 10.1007/s10347-005-0037-x

Orejas, C., Ferrier-Pages, C., Reynaud, S., Gori, A., Beraud, E., Tsounis, G., et al. (2011). Long-term growth rates of four mediterranean cold-water coral species maintained in aquaria. Mar. Ecol. Progr. Ser. 398, 149-155. doi: 10.11646/ zootaxa.852.1.1

Palardy, J. E., Grottoli, A. G., and Matthews, K. A. (2005). Effects of upwelling, depth, morphology and polyp size on feeding in three species of panamanian corals. Mar. Ecol. Progr. Ser. 300, 79-89. doi: 10.3354/meps300079

Porter, J. W. (1976). Autotrophy, heterotrophy, and resource partitioning in Caribbean reef-building corals. Am. Nat. 110, 731-742. doi: 10.1086/283100

Purser, A., Larsson, A. I., Thomsen, L., and van Oevelen, D. (2010). The influence of flow velocity and food concentration on Lophelia pertusa (Scleractinia) zooplankton capture rates. J. Exp. Mar. Biol. Ecol. 395, 55-62. doi: 10.1016/j. jembe.2010.08.013

Raes, M., and Vanreusel, A. (2005). "The metazoan meiofauna associated with a cold-water coral degradation zone in the Porcupine Seabight (NE Atlantic)," in Cold-Water Corals and Ecosystems, eds A. Freiwald and J. M. Roberts (Berlin: Springer), 821-847.

Raes, M., and Vanreusel, A. (2006). Microhabitat type determines the composition of nematode communities associated with sediment-clogged cold-water coral framework in the Porcupine Seabight (NE Atlantic). Deep Sea Res. I 53, 1880-1894. doi: 10.1016/j.dsr.2006.08.012

Raes, M., Vanreusel, A., and Decraemer, W. (2003). Epsilonematidae (Nematoda) from a cold-water coral environment in the Porcupine Seabight, with a discussion on the status of the genus Metaglochinema Gourbault \& Decraemer, 1986. Hydrobiologia 505, 49-72. doi: 10.1023/B:HYDR.0000007245.66840.0a

R Development Core Team (2010). R: A Language and Environment for Statistical Computing. Vienna: R Foundation for Statistical Computing.

Ricklefs, R. E., and Lovette, I. J. (1999). The roles of island area per se and habitat diversity in the species-area relationships of four lesser antillean faunal groups. J. Anim. Ecol. 68, 1142-1160. doi: 10.1046/j.1365-2656.1999.00358.x

Roark, E. B., Guilderson, T. P., Dunbar, R. B., Fallon, S. J., and Mucciarone, D. A. (2009). Extreme longevity in proteinaceous deep-sea corals. Proc. Natl. Acad. Sci. U.S.A. 106, 5204-5208. doi: 10.1073/pnas.0810875106

Roberts, J. M., Henry, L.-A., Long, D., and Hartley, J. P. (2008). Cold-water coral reef frameworks, megafaunal communities and evidence for coral carbonate mounds on the Hatton Bank, north east Atlantic. Facies 54, 297-316. doi: 10.1007/s10347-008-0140-x

Roberts, J. M., Wheeler, A., Freiwald, A., and Cairns, S. D. (2009). Cold-Water Corals: the Biology and Geology of Deep-Sea Coral Habitats. Cambridge: Cambridge University Press. doi: 10.1017/CBO9780511581588

Roberts, J. M., Wheeler, A. J., and Freiwald, A. (2006). Reefs of the deep: the biology and geology of cold-water coral ecosystems. Science 312, 543-547. doi: 10.1126/science.1119861
Rosenberg, R., Dupont, S., Lundalv, T., Skold, H. N., Norkko, A., Roth, J., et al. (2005). Biology of the basket star Gorgonocephalus caputmedusa (L.). Mar. Biol. 1, 43-50. doi: 10.1007/s00227-005-0032-3

Santavy, D. L., Courtney, L. A., Fisher, W. S., Quarles, R. L., and Jordan, S. J. (2013). Estimating surface area of sponges and gorgonians as indicators of habitat availability on Caribbean coral reefs. Hydrobiologia 707, 1-16. doi: 10.1007/s10750-012-1359-7

Sebens, K. P., Grace, S. P., Helmuth, B., Maney, E. J., and Miles, J. S. (1998). Water flow and prey capture by three scleractinian corals, Madracis mirabilis, Montastrea cavernoss and Porites porites in a field enclosure. Mar. Biol. 131, 347-360. doi: 10.1007/s002270050328

Sherwood, O., and Edinger, E. (2009). Ages and growth of some deep-sea gorgonian and antipatharian corals of Newfoundland and Labrador. Can. J. Fish. Aqua. Sci. 6, 142-152. doi: 10.1139/F08-195

Soetaert, K., Mohn, C., Rengstorf, A., Grehan, A., and van Oevelen, D. (2016). Ecosystem engineering creates a direct nutritional link between 600-m deep cold-water coral mounds and surface productivity. Sci. Rep. 6:35057. doi: 10. 1038/srep35057

Symonds, M. R., and Moussalli, A. (2011). A brief guide to model selection, multimodel inference and model averaging in behavioural ecology using Akaike's information criterion. Behav. Ecol. Sociobiol. 65, 13-21. doi: 10.1007/ s00265-010-1037-6

Tazioli, S., Bo, M., Boyer, M., Rotinsulu, H., and Bavestrello, G. (2007). Ecological observations of some common antipatharian corals in the marine park of Bunaken (North Sulawesi, Indonesia). Zool. Stud. 46, 227-241.

Thiem, O., Rvagnan, E., Fosså, J. H., and Berntsen, J. (2006). Food supply mechanisms for cold water corals along a continental shelf edge. J. Mar. Syst. 60, 207-219. doi: 10.1016/j.jmarsys.2005.12.004

Van Weering, T. C. E., de Haas, H., de Stigter, H. C., Lykke-Andersen, H., and Kouvaev, I. (2003). Structure and development of giant carbonate mounds at the SW and SE Rockall Trough margins, NE Atlantic Ocean. Mar. Geol. 198, 67-81. doi: 10.1016/S0025-3227(03)00095-1

Vytopil, E., and Willis, B. (2001). Epifaunal community structure in Acropora spp.(Scleractinia) on the great barrier reef: implications of coral morphology and habitat complexity. Coral Reefs. 200120, 281-288.

Wagner, D., Luck, D. G., and Toonen, R. J. (2012). The biology and ecology of black corals (Cnidaria: Anthozoa: Hexacorallia: Antipatharia). Adv. Mar. Biol. 63, 67-132. doi: 10.1016/B978-0-12-394282-1.00002-8

Wagner, D., and Opresko, D. M. (2015). Description of a new species of Leiopathes (Antipatharia: Leiopathes) from the Hawaiian Islands. Zootaxa 3974, 277-289. doi: 10.11646/zootaxa.3974.2.11

Wagner, D., Pochon, X., Irwin, L., Toonen, R. J., and Gates, R. D. (2011). Azooxanthellate? Most Hawaiian black corals contain Symbiodinium. Proc. $R$. Soc. B 278, 1323-1328. doi: 10.1098/rspb.2010.1681

Wang, Y.-P., Tew, K. S., Kuo, J., Ko, F.-C., and Meng, P.-J. (2012). The effect of coral polyp sizes and coral exudates on picoeukaryote dynamics in a controlled environment. Sci. Mar. 76, 455-461. doi: 10.3989/scimar.03 405.02A

Watling, L., France, S. C., Pante, E., and Simpson, A. (2011). Biology of deepwater octocorals. Adv. Mar. Biol. 60, 41-122. doi: 10.1016/B978-0-12-3855299.00002-0

Weaver, P. P., Boetius, A., Danovaro, R., Freiwald, A., Gunn, V., Heussner, S., et al. (2009). The future of integrated deep-sea research in europe: the HERMIONE project. Oceanography 22, 178-191. doi: 10.5670/oceanog.2009.18

Wheeler, A. J., Beyer, A., Freiwald, A., de Haas, H., Huvenne, V. A. I., Kozachenko, M., et al. (2007). Morphology and environment of cold-water coral carbonate mounds on the NW European margin. Int. J. Earth Sci. 96, 37-56. doi: 10.1007/s00531-006-0130-6

Wheeler, A. J., Kozachenko, M., Beyer, A., Foubert, A., Huvenne, V. A. I., Klages, M., et al. (2005). "Sedimentary processes and carbonate mounds in the Belgica mound province, Porcupine Seabight, NE Atlantic," in Cold-Water Corals and Ecosystems, eds A. Freiwald and J. M. Roberts (Berlin: SpringerVerlag), 571-603.

White, M., de Stigter, H., de Haas, H., and van Weering, T. (2003). Physical dynamics at the Rockall Trough margin that influence the carbonate mound and cold coral reef ecosystem. Ina Rep. ACES prog. Deliv. 11, 1-46. 
White, M., Roberts, J. M., and van Weering, T. (2007). Do bottom-intensified diurnal tidal currents shape the alignment of carbonate mounds in the NE Atlantic? Geo Mar. Lett. 27, 391-397. doi: 10.1007/s00367-007-0060-8

Wicksten, M. K. (1985). Carrying behavior in the family Homolidae (Decapoda: Brachyura). J. Crustac. Biol. 5, 476-479. doi: 10.2307/1547919

Wiedenmann, J., D’Angelo, C., Smith, E. G., Hunt, A. N., Legiret, F. E., Postle, A. D., et al. (2013). Nutrient enrichment can increase the susceptibility of reef corals to bleaching. Nat. Clim. Chang. 3:160. doi: 10.1038/nclimate 1661

Wijgerde, T., Spijkers, P., Larruppannan, E., Verreth, J. A. J., and Singa, R. (2012). Water flow affects zooplankton feeding by the scleractinian coral Galaxea fascicularis on a polyp and colony level. J. Mar. Biol. 7:854849. doi: 10.1155/ 2012/854849

Wilson, M. F. J., O'Connel, B., Brown, C., Guinan, J. C., and Grehan, A. J. (2007). Multiscale terrain analysis of multibeam bathymetry data for habitat mapping on the continental slope. Mar. Geod. 30, 3-35. doi: 10.1080/01490410701295962
Wright, D. J., Pendleton, M., Boulware, J., Walbridge, S., Gerlt, B., Eslinger, D., et al. (2012). ArcGIS Benthic Terrain Modeler (BTM), v. 3.0, Environmental Systems Research Institute, NOAA Coastal Services Center, Massachusetts Office of Coastal Zone Management. Available at: http://esriurl.com/5754

Conflict of Interest Statement: The authors declare that the research was conducted in the absence of any commercial or financial relationships that could be construed as a potential conflict of interest.

Copyright $\odot 2019$ De Clippele, Huvenne, Molodtsova and Roberts. This is an openaccess article distributed under the terms of the Creative Commons Attribution License (CC BY). The use, distribution or reproduction in other forums is permitted, provided the original author(s) and the copyright owner $(s)$ are credited and that the original publication in this journal is cited, in accordance with accepted academic practice. No use, distribution or reproduction is permitted which does not comply with these terms. 